\title{
Use of Mine Pool Water for Power Plant Cooling
}

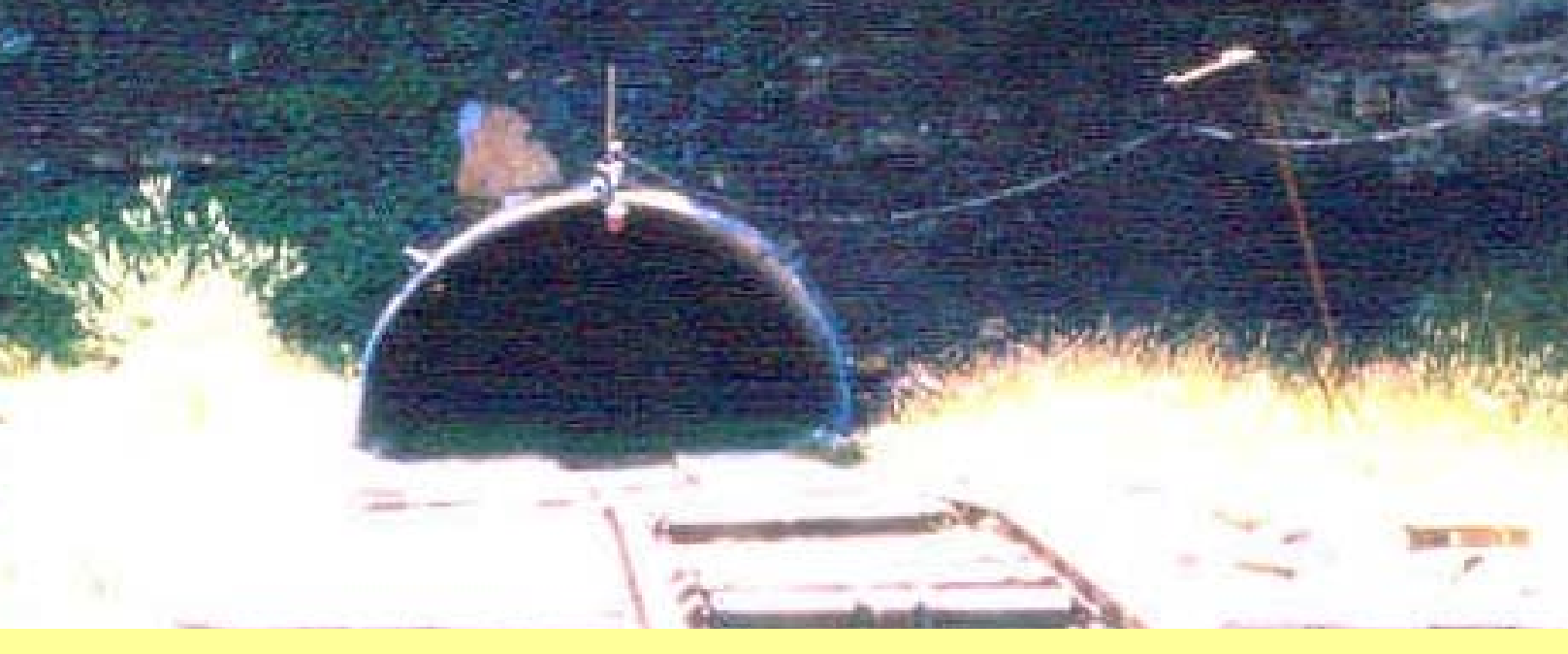

Prepared for:

Thomas J. Feeley, III

Product Manager - Innovations for Existing Plants Program U.S. Department of Energy

National Energy Technology Laboratory

Under contract W-31-109-Eng-38

Prepared by.

John A. Veil, John M. Kupar, and Markus G. Puder Argonne National Laboratory 


\section{Chapter 1 - Introduction}

Water and energy production issues intersect in numerous ways. Water is produced along with oil and gas, water runs off of or accumulates in coal mines, and water is needed to operate steam electric power plants and hydropower generating facilities. However, water and energy are often not in the proper balance. For example, even if water is available in sufficient quantities, it may not have the physical and chemical characteristics suitable for energy or other uses.

This report provides preliminary information about an opportunity to reuse an overabundant water source - ground water accumulated in underground coal mines - for cooling and process water in electric generating facilities. The report was funded by the U.S. Department of Energy's (DOE's) National Energy Technology Laboratory (NETL), which has implemented a water/energy research program (Feeley and Ramezan 2003). Among the topics studied under that program is the availability and use of "non-traditional sources" of water for use at power plants. This report supports NETL's water/energy research program.

\subsection{Background}

Coal has been extracted from the Appalachian Coal Basin of the Eastern United States for over two centuries. The main method of extraction, until the advent of World War II, was underground mining. After World War II, surface mining became the predominant method of coal extraction. As the underground mines closed in the anthracite coal fields of eastern Pennsylvania and the bituminous coal fields of western Pennsylvania and West Virginia, the pumping operations that kept the mines dry ceased operations. Over time, ground water accumulated in the voids left by the mining operations, creating large underground pools of water. The water quality varies as the result of the chemistry of the individual coal seam of the mine, the residence time of water in the mine, and the method of mining.

Old surface mines were left unrestored, and the exposed soils and rocks react with storm water and ground water to become contaminated with iron, manganese, and low $\mathrm{pH}$. Some of this water, as well as overflowing underground mines, drain to surface water bodies and can dramatically affect local water quality. Many streams that drain Appalachian coal mining regions have been blanketed by yellow-orange ferric hydroxide precipitate (colloquially known as "yellow boy") that ruins stream bottom habitat and lowers $\mathrm{pH}$ and oxygen levels.

Congress passed laws to control mining practices and operations in the 1970s. The Clean Water Act (CWA) established programs to control active discharges from industrial and municipal point sources, including coal mines. But the CWA does little to address nonpoint source releases of contaminated water from abandoned coal mining sites. The Surface Mining Control and Reclamation Act of 1977 (SMCRA) established programs to control modern surface coal mining to minimize environmental impacts and to restore lands and streams that had been damaged or degraded by past mining practices. The abandoned mine lands (AMLs) programs are well intended but are overwhelmed by the magnitude of restoration. Clean up of water in abandoned underground mines is not likely to be covered under SMCRA AML restoration programs. 
Although many underground mines are already actively releasing water to surface streams, several noteworthy underground mines in Pennsylvania and West Virginia are nearly filled with contaminated ground water and are expected to begin overflowing into nearby water bodies in the near future. Local communities are concerned that the influx of the mine pool water will damage their streams and potentially affect their potable water supplies. Local and state agencies are working on control strategies but recognize that easy and inexpensive solutions are not readily available.

\subsection{Potential Opportunity}

At least some of the underground mine pools present formidable environmental challenges to regulatory officials. However, with a change in philosophy and some creativity, this water can represent a potential untapped resource rather than a pollutant source. Many parts of the country are experiencing water shortages, brought on by both increasing demand and drier-than-normal rainfall years. Even the mid-Atlantic region, which historically has had abundant water resources, is nearing its surface water supply capacity in dry years like 2002. For example, the Pennsylvania Department of Environmental Protection's (PADEP's) drought information website, available at $<$ http://www.dep.state.pa.us/dep/subject/hotopics/drought/default.htm $>$ documents that many of Pennsylvania's counties experienced severe water shortages during 2002.

Although the composite demand for water resources has approached the mid-Atlantic region's capacity, new water demands continue to arise. One example relates to Maryland's recent efforts to deregulate electrical generation in the state. Several power companies have expressed interest in siting new generation facilities in the state (PPRP 2002). Duke Energy proposes to locate a new 640-MW facility about 50 miles upstream from Washington, DC on the Potomac River, and Mirant plans to expand the existing Dickerson plant, located a few miles downstream from the proposed Duke Energy facility, and add another $740 \mathrm{MW}$ of capacity. Both plants, if approved, would withdraw and consume several million gallons per day (MGD) of water from the Potomac River for makeup water in cooling towers. Because of overall water demands on the Potomac River, this incremental withdrawal volume cannot be guaranteed for the long term. Both new facilities are planning for large onsite water storage capacities that can be filled during periods of high or medium river flow. When the Potomac River is at low flow, the plants would utilize their stored water supplies rather than withdrawing each day from the river.

As power companies site new steam electric generation units in the mid-Atlantic region, they face serious concerns of water supply availability similar to those described above. Plants at estuarine and saltwater locations have sufficient water resources but inland plants do not. Underground mine pools in the Appalachian region may present a solution to water supply at some of these locations.

\subsection{Scope of Report}

This report is intended to provide a preliminary feasibility evaluation of using underground coal mine pool water for power plant cooling. It focuses on Pennsylvania and West Virginia because 
of the many coal mines located in those states. The report primarily evaluates use of mine water as makeup water for steam electric power plants with closed-cycle cooling technology (like wet cooling towers), but also reviews the scenario of using the mine pool as a closed-cycle cooling reservoir (by recirculating the water back to the underground mine where it can be naturally cooled), and as a source of once-through cooling water. Chapter 2 of the report characterizes the resource, including geography, numbers, volume, recharge rates, and hydrology. Chapter 3 describes the typical power plant cooling water requirements. Chapter 4 highlights location and transportation issues. Chapter 5 provides information about several power plants that are currently using or plan to use mine pool water. Chapter 6 discusses the regulatory picture. Chapter 7 addresses costs. Finally, the report presents the major findings and conclusions.

Although there are a few examples described in this report in which mine pools are being used for this purpose, many technical, legal, and policy questions remain before the practice can be conducted on a large scale. This report cannot and does not answer all the relevant questions. It is meant to be a first step that helps to identify the important issues, concerns, and barriers. Throughout the remaining chapters, we attempt to provide as much pertinent information as possible while operating under the constraints of a moderate budget and a short schedule. The report identifies those themes that have been researched and provides the references for the pertinent information. The report also highlights areas that require further study because information is nonexistent or inadequate. It is hoped that the findings presented in the report will serve as an incentive and springboard for future investigations on this subject.

\subsection{Conversion Factors}

Much of this report deals with volumes and flow rates of water. Several different quantitative units are commonly used. The report attempts to provide comparisons at key points in the text but for the convenience of readers, some conversion factors between common units are provided below in Table 1-1.

Table 1-1: Conversion Factors for Volume and Flow Rates

$\begin{array}{ll}\text { Volume } & 1 \text { million gallons }(\mathrm{MG})=3.07 \text { acre-feet } \\ & 1 \text { acre-foot }=325,851 \text { gallons or } 0.326 \mathrm{MG} \\ & 1 \text { cubic foot }=7.48 \text { gallons } \\ & 1 \text { cubic meter }=264.2 \text { gallons } \\ \text { Flow Rate } \quad & 1 \text { gallon per minute }(\mathrm{gpm})=0.00144 \mathrm{MG} / \text { day }(\mathrm{MGD}) \\ & 1 \text { cubic foot per second }(\mathrm{cfs})=448.8 \mathrm{gpm}=0.646 \mathrm{MGD} \\ & 1 \text { cubic meter per second }=35.3 \mathrm{cfs}=15,843 \mathrm{gpm}=22.8 \mathrm{MGD}\end{array}$




\section{Chapter 2 - Resource Characterization}

The full extent of the mine pool water resource in Pennsylvania and West Virginia has not been quantified. This chapter discusses the geographic distribution of the mine pool resource, the estimated quantities, where available, and the quality of the water in the main pools.

\subsection{Mine Pool Development}

The term mine pool has typically been used to characterize a volume of ground water that has accumulated in an underground mine after operations in the mine have ceased. This volume, in some cases, represents the volume of a single mine, but in many cases, it may represent the combined volume of several mines, or a mine complex. The following discussion provides an understanding of how initial mine development affects the size and nature of mine pools.

The majority of the coal extracted from the bituminous coal fields of western Pennsylvania and West Virginia as well as the anthracite fields of eastern Pennsylvania was mined using the room and pillar method of mining. Long wall mining was not introduced to the region until the mid $1970 \mathrm{~s}^{1}$. Initial mine development occurred with the construction of a main shaft to the coal bed. Auxiliary vertical shafts, such as ventilation and escape shafts, were also constructed at this time. The room and pillar method of mining consists of two steps in removing coal from a mine (Peng 1978, Reed et al. 1985). In the first step, entry points into the coal seam were developed followed by the mining of rooms into the seam. Half of the coal was left in place to serve as pillars to support the roof of the coal seam, allow access for removal of the coal, and provide ventilation. Mining proceeded from the main entry of the mine shaft to the back of the coal section. Once the rooms had been fully mined from a section, the second step of the process, referred to as pillar recovery, retreat mining, or second mining, occurred. Working from the rear of the section towards the entry point, each pillar was removed; in some cases, the roof collapsed when the pillars were removed. Pillar recovery would continue until the section had been completely mined.

In order to protect adjacent mines from flooding, fire, or explosions, mine operators normally left a 120- to 200-foot-wide strip of coal, referred to as a barrier pillar, along the boundary line of each mine. ${ }^{2}$ Prior to stricter mining regulations adopted in the early half of the 20th century, the pillars were commonly mined or robbed by miners, and these changes were never recorded on the mine maps. In other cases, miners from adjacent mines would enter previously abandoned mines to remove the pillar barriers.

\footnotetext{
${ }^{1}$ Matyus, J.P., 2003, personal communication from Matyus (Pennsylvania Department of Environmental Protection) to J.M. Kupar (Argonne National Laboratory).

${ }^{2}$ Matyus, J.P., 2003, personal communication from Matyus (Pennsylvania Department of Environmental Protection) to J.M. Kupar (Argonne National Laboratory).
} 
Underground mine operators in the bituminous coal fields of Pennsylvania and West Virginia mined coal either up-dip or down-dip in relation to the orientation of the coal seam (Cravatta et al. 1999). Mining up-dip provided mine operators the benefit of drier mines as the water would flow freely to discharge tunnels or other water control structures, thereby minimizing operating costs associated with pumping. Mining operations that followed the coal down-dip in relation to the coal seam generally had to employ extensive pumping equipment to keep the mine dry during the active life of the mine. The average depth of a mine in the bituminous coal fields is on the order of 500 feet below ground surface.

In the anthracite region of eastern Pennsylvania, mine development was influenced by steeply dipped deep coal seams that occurred in synclinal basins. Typically, these mines were developed as large underground complexes where mine operators could take advantage of working multiple coal seams that shared common shafts and interconnecting tunnels (Cravatta et al. 1999). These mines typically were developed below the regional water table, with the main shaft extending, in many cases, 1,800 feet deep. ${ }^{3}$ Extensive pumping was needed to keep the mines free from water.

When the mines became inactive, ground water flooded the mines. Water levels in the mine would continue to rise until hydraulic equilibrium with the regional water table was achieved or the water followed paths to topographically low areas. Fractures caused by roof cave-ins, removed or breached pillar barriers as well as tunnels and shafts, allowed water to freely flow within one mine or a series of mines (commonly referred to as mine complexes).

\subsection{Geologic Setting of Mine Pools}

The coal resources of Pennsylvania and West Virginia are located in the Northern region of the Appalachian Coal basin as shown in Figure 2-1. Mine pools exist only in areas where coal has been extracted from the earth by underground mining. This section discusses the occurrence and geographic distribution of coal resources in Pennsylvania and West Virginia.

\subsubsection{Pennsylvania}

Pennsylvania is located at the northern end of the Appalachian coal basin (Dodge 2003). Coal beds lie beneath approximately $33 \%$ of the state or about 15,000 square miles. The primary anthracite and bituminous economic resource coal beds are of Pennsylvanian age. There are two geographically distinct coal regions in the state: the bituminous region located in the western portion of the state, and the anthracite region, which is located in the north central-north eastern part of the state (Figure 2-2). These coal fields (Table 2-1) can be further subdivided into nine distinct fields (Dodge 2003).

\footnotetext{
${ }^{3}$ Ferco, M., 2003, personal communication from Ferco (Pennsylvania Department of Environmental Protection) to J.M. Kupar (Argonne National Laboratory).
} 


\title{
Table 2-1: Bituminous and Anthracite Coal Fields Of Pennsylvania
}

\author{
$\underline{\text { Bituminous Coal Fields }}$
}

Main Bituminous field

Georges Creek (Wellersburg) Field

Broad Top Field

North Central Field

\section{$\underline{\text { Anthracite Coal Fields }}$}

Western Northern Anthracite field

Northern Anthracite Field

Western Middle Anthracite field

Eastern Middle Anthracite field

Southern Anthracite field

The main bituminous field occurs within the Appalachian Plateau Physiographic province. The geologic structure of the western main bituminous field as well as the North-Central and Georges Creek coal fields can be characterized as a series of low northeast-southwest trending anticlines and synclines (Dodge 2003). As such, the coal beds tend to exhibit only a slight dip (commonly $2 \%$ and up to $8 \%$ ) as opposed to the coal beds in the anthracite region.

The anthracite region occurs in the Ridge and Valley Physiographic province. The geologic structure of the four eastern anthracite fields consists of one or more deep, steep-sided synclinal basins. Coal beds exhibiting dip in excess of 60 degrees have been measured in some anthracite coal fields.

\subsubsection{West Virginia}

West Virginia is located in both the northern and central region of the Appalachian coal basin. Unlike Pennsylvania, West Virginia's only coal resource is bituminous coal. The major coal beds, which have been mined or are currently mined, are of Pennsylvanian age and occur in the northern, western and southern portions of the state (Figure 2-3). Coal beds underlie approximately $73 \%$ of the state or about 17,000 square miles (Repine et al. 1992). The state's coal fields are divided into two major producing regions - the northern field and the southern field.

The state's coal fields all lay within the Appalachian Plateau physiographic province. The geologic structure of the coal fields can be characterized as a broad series of low northeastsouthwest trending folds. As such, the coal beds tend to exhibit only a slight dip.

Historically, the majority of the coal produced in West Virginia has come from underground mines (West Virginia Coal Association 2001). In 2000, 63\% of the coal produced in the state 
(109,395,146 tons), was produced from underground mines (West Virginia Coal Association 2001). The main coal-producing formations of West Virginia and associated coal beds are identified in Table 2-2 (Repine et al. 1992).

Table 2-2: Major Coal-Producing Formations and Associated Primary Coal Beds of West Virginia

Formation

Allegheny

Conemaugh

Kanawha

Monongahela Group

New River

Pocahontas

\section{$\underline{\text { Coal Bed }}$}

Lower Kittanning/No. 5 Block coal

Upper Freeport Coal bed

Campbell Creek

Winifrede Coal Bed

Coalburg Coal Bed

Stockton Coal Bed

Pittsburgh Coal Bed

Redstone Coal Bed

Sewickly

Waynesburg

Fire Creek

Beckley

Sewell

No. 3, No. 4, and No. 6 Pocahontas Coal Beds

\subsection{Distribution and Volume Estimates of the Mine Pool Water Resource}

Comprehensive inventories of mine pools or mine pool complexes currently do not exist for either West Virginia or Pennsylvania. Some data has been generated on specific coal fields in the anthracite region of Pennsylvania. In other cases, evaluations of individual mines in the bituminous coal fields of each state have occurred. Notwithstanding the lack of a comprehensive inventory for either state, data have been generated, which, when presented on a collective basis, can identify the potential for using mine pool water as cooling water at power plants or for other industrial needs.

\subsubsection{Geographic Distribution of Mine Pools}

The Pennsylvania Department of Environmental Protection (PADEP) produced a map in April 2003 that inventoried mine discharge sites with flows of greater than $250 \mathrm{gpm}$ (Figure 2-4). The sites shown on the map represent 43 of the state's high priority sites in the anthracite coal fields and 101 state high-priority sites in the bituminous coal fields. 
The map clearly shows the geographic distribution of the mine discharge sites that have the potential to be considered as source of cooling water for power plants. This map represents only a small fraction of underground abandoned mines in both the anthracite bituminous coal fields. PADEP estimates that there are between 10,000 and 15,000 abandoned underground mines in Pennsylvania. ${ }^{4}$ Records in the form of mine maps and mine permits do exist for the majority of the abandoned underground mine sites. Given sufficient resources, the state could digitize this information and delineate the size of the mine pool resource in Pennsylvania. There are a number of underground mine sites that do not have any information or at this point have not been found.

The West Virginia Geological and Economic Survey (WVGES) estimates that there are up to 100,000 abandoned underground mines in West Virginia. ${ }^{5}$ Included in this number are small mines that would make up a significant percentage of the total estimate. These small mines would represent a minor addition to the overall mine pool resource of the state. The WVGES currently has in storage 44,000 image mine maps, 37,000 of which represent unique mine images. The current distribution of known underground discharge locations in the state of West Virginia is shown in Figure 2-5.

\subsubsection{Volume Estimates of Mine Pools}

As mentioned earlier in this section, there has not been a comprehensive statewide inventory of the mine pool water resource in either Pennsylvania or West Virginia. However, there have been limited studies that developed volume estimates of mine pools on specific coal fields or coal seams. Several examples of theses studies will be presented in this section.

In the first study of its kind, the National Mineland Reclamation Center (NMRC) at West Virginia University is undertaking a four-year effort to map the underground mines and their associated mine pools of the Pittsburgh coal seam in western Pennsylvania and in the northern coal field of West Virginia. The Pittsburgh coal seam is a significant coal resource that underlies western Pennsylvania and northern West Virginia. To date, NMRC has mapped 130 underground coal mines in both Pennsylvania and West Virginia. ${ }^{6}$ NMRC has estimated the combined storage volume of these mines to be 250 billion gallons (768,000 acre-ft). To put this in perspective, a volume of water that would fill a space of one cubic mile is about 4 times larger (about 1,100 billion gallons) and the volume of Lake Erie is more than 500 times larger (about 127,000 billion gallons). The average flow of the Potomac River near Washington, DC, is about 7 billion gallons per day.

\footnotetext{
${ }^{4}$ Callahan, Thomas, J.P., 2003, personal communication from Callahan (Pennsylvania Department of Environmental Protection) to J.M. Kupar (Argonne National Laboratory).

${ }^{5}$ Fedorko III, Nick. 2003, personal communication from Fedorko (West Virginia Geological and Economic Survey) to J.M. Kupar (Argonne National Laboratory).

${ }^{6}$ Leavitt, Bruce, 2003, personal communication from Leavitt (consultant to National Mineland Reclamation Center) to J.M. Kupar (Argonne National Laboratory).
} 
The NMRC study includes 499 square miles of flooded mines. The estimated discharge volume from the underground mines in the current study is 19.1 billion gallons per year. This volume will continue to increase as new mines are mapped and included in the database. Table 2-3 provides additional detail of the 130 underground mines in this study.

Table 2-3: Details of Mine Pool Water Volume Estimates in NMRC Study

\begin{tabular}{llccc} 
State & County & $\begin{array}{c}\text { Number of } \\
\text { Mines }\end{array}$ & $\begin{array}{c}\text { Estimated } \\
\text { Volume } \\
\text { (million gallons) }\end{array}$ & $\begin{array}{c}\text { Estimated } \\
\text { Volume } \\
\text { (acre-ft) }\end{array}$ \\
& Wennsylvania & 33 & 49,300 & 151,000 \\
& Greene & 15 & 78,500 & 241,000 \\
& Allegheny & 4 & 2,500 & 7,700 \\
& Fayette & 38 & 48,300 & 148,000 \\
West Virginia & Harrison & 8 & & \\
& Marion & 20 & 4,900 & 15,000 \\
& Monongalia & 11 & 35,600 & 109,000 \\
& Brooke & 1 & 30,700 & 94,000 \\
\hline Total & & 130 & 223 & 685 \\
\hline & & & 250,000 & 768,000
\end{tabular}

The U. S. Geological Survey conducted a study in 1975 to locate, measure, and sample mine discharges in the four coal fields in the anthracite region of Pennsylvania (Growitz 1985). Data collected during this study were compared to data collected in previous studies (Ash 1949, 1951). In the earlier studies (Ash 1949, 1951), water elevations were measured in each mine sampled and the water capacity/volume was calculated. In the more recent study (Growitz 1985), water elevations were again measured and the water volume of each mine recalculated. The data presented in Table 2-4 represent the water capacity/volume of selected mines in the Western Middle Anthracite Coal Field.

Table 2-4: Estimated Water Capacity for Selected Mines of the Western Middle Anthracite Coal Field

Mine

Shenandoah Complex

Knickerbocker

North Mahanoy

Mahanoy City

Kebley Run

Indian Ridge

Maple Hill

Kohinoor

\section{Estimated \\ Capacity \\ (Acre Feet)}

1,000

1,000

3,000

200

5,000

10,000

10,000

\section{Estimated Capacity \\ (Million Gallons)}

326

326

977

65

1,630

3,260

3,260
Observed Flow

$\left(\mathbf{f t}^{3} / \mathbf{s}\right)$ 


\begin{tabular}{|c|c|c|c|}
\hline Mine & $\begin{array}{c}\text { Estimated } \\
\text { Capacity } \\
\text { (Acre Feet) }\end{array}$ & $\begin{array}{l}\text { Estimated Capacity } \\
\text { (Million Gallons) }\end{array}$ & $\begin{array}{c}\text { Observed Flow } \\
\left(\mathbf{f t}^{\mathbf{3}} / \mathbf{s}\right)\end{array}$ \\
\hline Weston & 5,000 & 1,630 & \\
\hline William Penn & 4,000 & 1,300 & \\
\hline East Bear Ridge & 1,460 & 476 & \\
\hline Raven Run & 1,170 & 382 & \\
\hline Hammond & 3,000 & 977 & \\
\hline Packer No. 5 & 5,000 & 1,630 & 42.7 \\
\hline \multicolumn{4}{|l|}{ Other } \\
\hline Vulcan Buck Mountain & 6,100 & 1,990 & 7.4 \\
\hline Centralia & 924 & 301 & \\
\hline Preston No. 3 & 1,750 & 570 & \\
\hline Bast & 13,000 & 4,240 & \\
\hline Tunnel & 1,894 & 617 & 11.0 \\
\hline Midvalley 1,2 , and 3 & 1,500 & 489 & 5.9 \\
\hline Locust Gap & 5,000 & 1,630 & 13 \\
\hline Enterprise and Excelsior & 2,600 & 847 & 13 \\
\hline Reliance and Alaska & 6,000 & 1,955 & \\
\hline Big Mountain & 2,530 & 824 & \\
\hline Bear Valley and Bear Valley & 4,060 & 1,323 & \\
\hline \multicolumn{4}{|l|}{ Slope } \\
\hline Burnside & 3,390 & 1,100 & \\
\hline Henry Clay Stirling & 8,250 & 2,688 & 11.0 \\
\hline Cameron & 7,000 & 2,280 & 9.81 \\
\hline Luke Fidler & 2,500 & 814 & \\
\hline Hickory Swamp & 400 & 130 & \\
\hline Glen Burn & 1,000 & 326 & \\
\hline North Franklin & 4,900 & 1,596 & 8.3 \\
\hline Richards Shaft & 5,025 & 1,637 & \\
\hline Sayre-Sioux & 3,490 & 1,140 & \\
\hline Pennsylvania & 6,500 & 2,120 & \\
\hline Scott and Scott Ridge & 4,500 & 1,470 & \\
\hline Richards, Natalie, Greenough & 3,140 & 1,020 & \\
\hline Total & 145,283 & 47,346 & \\
\hline
\end{tabular}

Longview Power LLC, a wholly owned subsidiary of GenPower LLC, conducted a study in 2002 to identify sources of water from mine pools in southwest Pennsylvania to use as cooling water for a proposed 600-MW coal-fired plant to be located near Morgantown, West Virginia ${ }^{7}$. The study identified several mines in the Pittsburgh coal seam that have sufficient volume capacity

${ }^{7}$ Colbert, Christopher, 2003, personal communication and email from Colbert (GenPower, LLC) to J.M. Kupar (Argonne National Laboratory). 
and sustainability to provide a long-term source of cooling water. Eight candidate mines were identified, and the flooded volume of each mine was calculated. Table 2-5 provides the identification of each mine, the water elevation (as measured in 2002), the surface area covered above the mine, and the flooded water volume. GenPower also evaluated the Shannopin mine, which is located near its proposed power plant site. Although that mine is conveniently located, its mine pool water has poorer water quality (high acidity, low $\mathrm{pH}$, and high total dissolved solids or TDS) than the other local mines. In light of the potential cost for treating this water, GenPower initially evaluated other options. Because this mine represents a near-term environmental threat to nearby surface water resources, the State of Pennsylvania asked GenPower to reconsider using this water. On September 25, 2003, Governor Edward Rendell of Pennsylvania announced that an innovative public/private partnership had been formed between PADEP, the Pennsylvania Department of Community and Economic Development, the Pennsylvania Infrastructure Investment Authority, AMD Reclamation Inc., and Dana Mining to treat the Shannopin mine water (http://biz.yahoo.com/prnews/030925/phth036a_1.html). GenPower has shifted its focus back to the Shannopin mine as a source of cooling water. If the Longview power plant is constructed, the company now plans to use treated water from the Shannopin and other nearby mines.

Table 2-5: Mine Volumes of Selected Mines of the Pittsburgh Coal Seam, Southwestern Pennsylvania ${ }^{8}$

\begin{tabular}{lcccc} 
Mine & Water Level & $\begin{array}{c}\text { Mine Area } \\
\left(\mathbf{m i l l i o n} \mathbf{f t}^{\mathbf{2}} \mathbf{)}\right.\end{array}$ & $\begin{array}{c}\text { Flooded Volume, } \\
\mathbf{( m i l l i o n}_{\text {gallons })}\end{array}$ & $\begin{array}{c}\text { Flooded Volume } \\
\text { (acre-ft) }\end{array}$ \\
Humphrey & 800 & 753.2 & 12,700 & 39,000 \\
Pursglove & 800 & 408.8 & 6,880 & 21,000 \\
Osage & 800 & 511.1 & 8,600 & 26,000 \\
Arwright & 800 & 527.2 & 8,870 & 27,000 \\
Robena & & 656.3 & 11,050 & 34,000 \\
Dilworth & 850 & 334.6 & 5,630 & 17,000 \\
Christopher & 850 & 32.58 & 548 & 1,700 \\
Maiden \#1 & 885 & 34.88 & 587 & 1,800 \\
\hline Total & & & 54,900 & 169,000
\end{tabular}

\subsection{Sustainable Yield - Recharge Potential of Mine Pools}

There are many factors that affect the rate of ground water recharge to a mine pool. Some of these factors include precipitation, regional drainage patterns, the amount of drainage area underlain by coal measures, local geologic conditions, and the lithology over the mine (the overburden). Recharge of a mine pool can also be affected by the hydraulic influence of water bodies, such as streams and rivers.

\footnotetext{
${ }^{8}$ Colbert, Christopher, 2003, personal communication and email from Colbert (GenPower, LLC) to J.M. Kupar (Argonne National Laboratory).
} 
Growitz (1985) calculated the water yield of the coal fields in the anthracite region in

Pennsylvania. Much of these data were derived from previous work of Ash $(1941,1946)$. Table 2-6 provides an estimate of water yield on a regional basis for the mine pools located in the four coals fields in the anthracite region. The data were generated based on measurements of outfalls of mines in the various coal fields.

Another indicator of the potential rate of ground water recharge to a mine pool is the rate of discharge of a mine outfall. This is only an observed indicator, however, as there are many factors that will determine the actual recharge rate of a mine pool. Cravotta et al. (1999) measured several mine outfalls in 1999 in both the anthracite and bituminous coalfields of Pennsylvania. Table 2-7 provides a listing of the largest measured outfalls.

Table 2-6: Summary of Area of Coal Measures, Drainage Area, and Water Yield of the Four Coal Fields of the Anthracite Region in Eastern Pennsylvania9

$\begin{array}{lcccc}\text { Coal Field } & \begin{array}{c}\text { Area of Coal } \\ \text { Measures } \\ \left(\mathbf{m i l e}^{\mathbf{2}}\right)\end{array} & \begin{array}{c}\text { Total Drainage } \\ \text { Area of Each } \\ \text { Field }\left(\mathbf{m i l e}^{\mathbf{2}}\right)\end{array} & \begin{array}{c}\text { Yield of Water } \\ \left(\mathbf{f t}^{\mathbf{3}} / \mathbf{s} / \mathbf{m i l e}^{\mathbf{2}}\right)\end{array} & \begin{array}{c}\text { Yield of W } \\ \left(\mathbf{g p m} / \mathbf{m i l}^{2}\right)\end{array} \\ \text { Northern } & 160 & \text { NA } & 2.1 & \\ \text { Eastern Middle } & 32 & \text { NA } & 5.5 & 943 \\ \text { Western Middle } & 75 & 100 & 2.6 & 1,170 \\ \text { Southern } & 141 & 270 & 1.5 & 674\end{array}$

Table 2-7: Selected Mine Discharges from the Anthracite and Bituminous Coal Fields of Pennsylvania

$\begin{array}{llcc}\text { Coal Type } & \text { Site } & \begin{array}{c}\text { Discharge } \\ \mathbf{V o l u m e}^{\mathbf{3}} \mathbf{( \mathbf { s } )}\end{array} & \begin{array}{c}\text { Discharge Volume } \\ \mathbf{( g p m )}\end{array} \\ \text { Anthracite } & \text { Truesdale \# 2 } & 5 & 2,240 \\ \text { Anthracite } & \text { Bell Water Level Tunnel } & 22 & 9,800 \\ \text { Anthracite } & \text { Big Mountain mine } & 1 & 450 \\ \text { Anthracite } & \text { Derringer Tunnel } & 13 & 5,800 \\ \text { Anthracite } & \text { Gravity Slope } & 11 & 4,900 \\ \text { Anthracite } & \text { Jeddo Mine Tunnel } & 78 & 35,000 \\ \text { Anthracite } & \text { Jermyn Outfall } & 34 & 15,000 \\ \text { Anthracite } & \text { Old Forge Borehole } & 78 & 35,000 \\ \text { Anthracite } & \text { S. Wilkes Barre Boreholes } & 32 & 14,000 \\ \text { Bituminous } & \text { Gillespie Run (05) } & 5 & 2,240 \\ \text { Bituminous } & \text { N. Branch Plum Creek (06) } & 2 & 900 \\ & & & \\ \text { }{ }^{9} \text { Data obtained from Growitz, Douglas, L. 1985 USGS Water Resources Report 83-4274, Reconnaissance of Mine } \\ \text { Drainage in the Coal Fields of Eastern Pennsylvania. Table 38 modified to include drainage acreage of each coal } \\ \text { field. }\end{array}$




$\begin{array}{llcr}\text { Bituminous } & \text { Berwind Mine (018) } & 6 & 2,700 \\ \text { Bituminous } & \text { Little Conemaugh (019) } & 4 & 1,800 \\ \text { Bituminous } & \text { Browns Run (025) } & 7 & 3,100 \\ \text { Bituminous } & \text { Sewickley Creek (084) } & 6 & 2,700 \\ \text { Bituminous } & \text { Tinkers Run (091) } & 10 & 4,500\end{array}$

\subsection{Potential Issues Related to Water Withdraw from Mine Pools}

The withdrawal of significant volumes of water from a mine pool, in excess of the mine pool's recharge rate, may affect the local hydrology or increase the likelihood of subsidence. PADEP has expressed concern that removing water from the pore space of the remaining coal or other rock in an abandoned underground mine may cause portions of the mine roof to collapse. ${ }^{10}$ If the mine's roof collapses, there is a potential of subsidence at the surface and fracturing of the strata above the mine. The likelihood of subsidence is dependent upon several factors (Office of Surface Mining 2002), including:

- the method of mining,

- the nature and thickness of the overlying rock strata over the mine,

- the thickness of the original coal seam and the amount removed, and

- the overall design of the mine in relation to the orientation of coal seams.

The effects of subsidence can include:

- $\quad$ structural damage to infrastructure, such as roads, pipelines and buildings,

- alteration of the local hydrologic balance, and

- impacts on both ground and surface water flow.

When a mine roof collapses, fracturing can occur into the overlying strata. Cracks can occur as long as 60 times the width of the coal seam. ${ }^{11}$ If the fractures penetrate the confining layer of an aquifer, the potential exists that the aquifer will drain into the mine or other porous formations and cause a drop in the potentiometric surface of the aquifer. This would have the effect of either lowering the water elevations of local water wells or drying them up completely.

While the concerns noted above express the potential effects of removing large amounts of water from a mine pool, PADEP has indicated that it has not observed any subsidence as the result of withdrawal of mine pool water by power plants for cooling. ${ }^{12}$ Most of the newer mines in western Pennsylvania utilize the long wall mining method, which effectively collapses the mine

\footnotetext{
${ }^{10}$ Matyus, J.P, and T. Callahan, 2003, personal communication from Matyus and Callahan (Pennsylvania Department of Environmental Protection) to J.M. Kupar (Argonne National Laboratory).

${ }^{11}$ Matyus, J.P., 2003, personal communication from Matyus (Pennsylvania Department of Environmental Protection) to J.M. Kupar (Argonne National Laboratory).

${ }^{12}$ Schueck, J., 2003, personal communication from Schueck (Pennsylvania department of Environmental Protection) to J.M. Kupar (Argonne National Laboratory)
} 
behind the mining operation. The older mines in this region utilized the room and pillar method of mining. In this case, the pillars are robbed (or removed) towards the end of the operational life of the mine. When utilizing this mining method, the roof of the mine can also collapse.

Subsidence in these areas would have been noticed within a short period of time. Mine pool water in the eastern anthracite region is withdrawn from older, deeper mines or from mine drainage outfalls. As in the case of the western mines, there has been no observed subsidence as the result of withdrawing water from mines pools in the anthracite region. However, each proposed location must be studied to insure that there is not a local anomaly that may cause subsidence and affect local hydrology.

Another conceivable, albeit largely unexplored, issue would involve withdrawal, recharge, and interference scenarios where the more or less contaminated mine pool water is replaced with clean groundwater that is thus no longer available to localities supplying drinking water or thirdparty well owners. A determination of the relative likelihood of such scenarios would require case-specific hydrogeological expertise.

\subsection{Summary of Mine Water Quality}

The nature and quality of mine pool water in the bituminous and anthracite coal fields in Pennsylvania and West Virginia has been extensively studied as a result of the impacts of this water when discharged to the environment. Cravotta et al. (1999) observed that mine pool water in these coal fields exhibits a bimodal frequency distribution of $\mathrm{pH}$ with two peaks of $\mathrm{pH} 2.5$ to 4 (acidic) and pH 6 to 7 (near-neutral). The mine pool water will also exhibit elevated levels of TDS, iron, aluminum, sulfate and other dissolved metal ions.

Mine pool water becomes acidic from the reaction of oxygen and water with iron-sulfide-bearing minerals found in the coal, such as pyrite $\left(\mathrm{FeS}_{2}\right)$. Near-neutral $\mathrm{pH}$ mine pool water results from the buffering of mine pool water with calcareous minerals, such as calcite $\left(\mathrm{CaCO}_{3}\right)$. There are many factors that affect the chemistry of mine pool water. Wood (1995) suggests that the following factors will affect the $\mathrm{pH}$, acidity, and metals concentrations in the discharged water:

- mineralogy of the coals and overburden;

- quantity of water flowing through the mine;

- residence time, path length and depth of water circulation through the mine;

- availability of oxygen in the mine water;

- mine design (e.g., up-dip versus down-dip);

- active pumping, either within the mine or within the influence of adjacent mines; and

- exposed surface of sulfide minerals. 


\section{Chapter 3 - Cooling Water Requirements}

If mine pool water is going to be used as a source of power plant cooling and process water, it must meet the volumetric, thermal, chemical, and physical requirements of the destination plants. This chapter outlines four different possible cooling water operational modes and the requirements needed to fulfill the cooling needs for each mode. Portions of this chapter are based on a report evaluating cooling tower performance, jointly prepared by the DOE Office of Fossil Energy (DOE/FE), NETL, and Argonne National Laboratory (DOE 2002) - to evaluate cooling tower performance.

\subsection{The Need for Cooling Water}

Water is used in many industrial applications to cool machinery or to condense steam. The largest industrial user of cooling water is the steam electric power industry. Data from a 1998 U.S. Geological Survey (USGS) report indicate that steam electric power generation uses approximately 190 billion gallons (583,000 acre-ft) of water per day (USGS 1998). Of this total, 132 billion gallons (405,000 acre-feet) was fresh water and 58 billion gallons (178,000 acre-feet) was saline water. In 1999, more than 60 percent of the utility power-generating capacity in the United States (382,270 MW) utilized the steam-electric process (EIA 2000).

At nuclear and fossil-fueled steam electric power plants, electricity is produced by heating purified water to create high-pressure steam. The steam is expanded in turbines driving the generators that produce electricity. After leaving the turbines, the steam passes through a condenser that has multiple tubes and a large surface area. A large volume of cool water circulates through the tubes, absorbing heat from the steam. As the steam cools and condenses, the temperature of the cooling water rises. Steam condensers are designed to produce a vacuum at the outlet end of the turbine, thereby increasing the efficiency of the system. The temperature of the cooling water exiting the condenser affects the performance of the turbine - the cooler the temperature, the better the performance. As cooling water temperatures decrease, a higher level of vacuum can be produced and additional energy can be extracted.

\subsection{Cooling Water Operational Modes}

Mine pool water could be used for once-through or closed-cycle cooling. At least four operational modes are conceivable.

\subsubsection{Once-Through Cooling}

Once-through cooling systems withdraw large volumes of water - typically in the range of tens of millions to billions of gallons per day from a river, lake, estuary, or ocean. The water is pumped through the condenser in a single pass and returned to the same or a nearby water body. Mine pools offer two possible modes for once-through cooling. Under Mode 1, Once-Through with Discharge, which is closest to the generic form of once-through cooling described above, the water is withdrawn from the mine pool, passed through the condenser, and then discharged into a nearby stream (Figure 3-1). 
Under Mode 2, Once-Through, Return to Pool, water is withdrawn from the mine pool, passed through the condenser, and then returned to the mine pool either at the surface of the pool or at a lower depth (Figure 3-2). Because Mode 2 does not reduce the volume of the mine pool, there is little chance that its use in this way would contribute to subsidence of the ground over the mine.

\subsubsection{Closed-Cycle Cooling}

The second category of cooling uses a closed-cycle cooling system, in which the water used to cool the condenser is not directly discharged but rather is recirculated to a separate structure for cooling before being returned to the condenser. Evaporation, drift of water droplets in a plume, and planned cooling tower blowdown (periodic discharges of portions of the recirculating water to remove build up of solids and other undesirable constituents) remove cooling water from the evaporative system, effectively consuming that water. Information provided to DOE/NETL by FirstEnergy shows that the evaporation and drift loss are four times higher than the blowdown flow (Feeley undated). This ratio varies depending on ambient temperature and humidity but indicates that evaporative and drift losses are significant and an integral component of wet cooling towers. Most of the makeup water in a recirculating system is needed to replace water lost to evaporation and drift. By comparison, once-through cooling systems return the heated water to the source water or a nearby water body. The heated discharge enhances the rate of surface evaporation from the receiving stream but most of the water is retained in the receiving water body and is not consumed.

Regular additions of "makeup" cooling water are needed to replace the water consumed in a recirculating system. Makeup volumes are much lower than daily once-through volumes, and may range from hundreds of thousands to millions of gallons per day. The USGS estimates that about 2 percent of the water withdrawn for steam electric power generation in the United States is consumed as a result of once-through cooling, cooling towers, or pond cooling (USGS 1998).

Mine pools also offer two possible modes for closed-cycle cooling. Under Mode 3, ClosedCycle, Wet Tower, makeup water is withdrawn from the mine pool and added to the recirculating cooling system, which uses a wet cooling tower. Some water is lost to evaporation and plume drift, and blowdown is typically discharged into a nearby stream (Figure 3-3). Because the volume of makeup water is much lower than that of once-through cooling water for a comparably sized plant, the volume and hydrological recharge rate for the mine pool do not need to be as high as they would under Mode 1 .

Under Mode 4, Closed-Cycle, Cooling Loop, little or no water is withdrawn from the mine pool. Instead, a long, continuous coil of heat-exchange tubing is placed into the mine pool (Figure 3-4). Warm water or some other heat exchanging fluid is circulated from the condenser through the cooling loop and then back to the condenser. In the absence of leaks, the fluid inside the cooling system never comes in contact with the mine pool. Heat is exchanged through the walls of the cooling loop tubing. This type of system is essentially a giant heat pump. 


\subsection{Downstream Use after Instream Transport}

The four cooling modes described above involve direct withdrawal and use of the mine pool water by the plant. A fifth mode involves use of the water by a power plant located downstream from the mine pool site. Under Mode 5, Downstream Use after Instream Transport, water is withdrawn from the mine, treated if necessary to meet water quality requirements, and then discharged to and transported by a river or stream to a downstream location where it can be used. The river would serve as a conduit for the mine pool water (Figure 3-5). At the downstream withdrawal location, the power plant would be allowed to withdraw an amount of water equal to or less than the amount previously added at the mine site. Depending on the cooling system employed at the power plant, the transported mine pool water could serve as once-through cooling water or as cooling tower makeup water.

This incremental water volume offers several benefits. Because the augmented river flow would be higher than normal, the mine pool water would further provide additional aquatic habitat for a distance many miles downstream from the point of discharge to the point of withdrawal at the power plant site. The incremental volume would also provide additional flow to dilute permitted and unpermitted discharges to the stream.

Previously, Mode 5 has been just an interesting concept. Section 5-2 describes an actual trial in eastern Pennsylvania during the summer of 2003, in which mine pool water was discharged to a tributary of the Schuylkill River and used by a large nuclear power plant more than 70 miles downstream.

Under the most generic form of Mode 5 operation, the mine would release the same or a higher volume of water, which is subsequently withdrawn by a downstream user. Presumably, a power plant would have relatively consistent water supply needs throughout the year so this would lead to relatively constant mine pool releases. However, any regulatory requirements for releasing treated mine water to a stream need not stipulate a constant volume at all times. The state agencies responsible for natural resources and environmental protection may actually prefer and welcome a discharge volume higher than needed by the power plant during dry or low-flow periods, and a lower than needed volume during normal or high-flow conditions. Innovative scheduling of mine pool discharges can provide even greater environmental benefits.

The potential regulatory requirements governing the use of a stream to transfer water from a mine pool to a downstream plant are discussed in Section 6.6 of Chapter 6 .

\subsection{Cooling Water Volume Needed}

The volume of water needed to cool a generating unit depends on various factors that plant designers must consider. Some of the key questions include the following:

- What is the temperature of the incoming cooling water?

- What is the difference in temperatures between the cold water entering the condenser and the hot water leaving the condenser? 
- What is the approach (the minimum difference between fluid stream temperatures in a heat exchanger)? In a condenser, it is the difference between the condensing steam temperature and the temperature of the cooling water exiting the condenser. The approach for a given heat exchanger is typically chosen as a design parameter that reflects how close the operation of that heat exchanger comes to the thermodynamic limits on the amount of heat that can be transferred between the two fluid streams. When increasing the surface area in the design of a given heat exchanger, a lower approach can be achieved, and the unit comes closer to transferring the highest amount of heat theoretically possible.

- What are the wet-bulb and dry-bulb air temperatures for plants using cooling towers?

- What is the available volume of water that can be: a) withdrawn and b) consumed without return to the original source?

- For once-through systems, what are the thermal discharge limits for the heated cooling water?

- For cooling towers, what are the number of cycles of concentration - the concentration of total dissolved solids and other important chemical parameters that determine how many times the water can be recirculated before having to replenish it with makeup water?

Listing those factors shows that the relationship between power production and cooling water volume is not likely to be constant. Figure 3-6 displays data provided to the authors by Wayne Micheletti, a power plant cooling water systems specialist (Micheletti 2003). He used selected data from the COOLADD database (EPRI 1998) to demonstrate the relationship. The flow is the circulating cooling water flow. For once-through systems, this is the total flow withdrawn and subsequently discharged. For closed-cycle systems, this is the total water volume that flows in a closed-loop between the condenser and the cooling tower. The actual daily new water requirements for a closed-cycle system are much smaller, and are used as makeup flow.

Figure 3-6 represents hundreds of data points from actual U.S. power plants that have been distilled into two polynomial regression lines, one for closed-cycle systems and the other for once-through systems. The raw data (not included in this report) show some degree of scatter around the line, suggesting that actual gpm/MW ratios are variable and site-specific. But for the sake of discussion, these two curves are reasonable approximations. On the average, closed-cycle systems operate on a temperature rise through the condenser of $24^{\circ} \mathrm{F}$ while once-through systems have a temperature rise of $20^{\circ} \mathrm{F}$ (Micheletti and Burns 2002). The heat rejected from a power plant is the product of cooling water flow rate and temperature; the relationship is proportional. Therefore, if an average once-through plant has a temperature rise that is slightly smaller than an average closed-cycle plant, it will have a cooling water flow rate that is slightly larger, as demonstrated by the separation between the two regression lines. Another important point about the graph is that the ratio of gpm/ $\mathrm{MW}$ is not constant; it increases as the plant capacity rises.

The flow required by a power plant of a given capacity can be estimated by visual interpolation from the appropriate regression line or by applying one of the regression equations specified in the chart. The cooling water volume needed for a hypothetical, generic 400-MW coal-fired 
power plant can be derived using the two curves. The volume needed for once-through cooling (Mode 1) is about 254,000 gpm (365 MGD). Mode 1 will only work if the volume of the mine pool is sufficiently large so that hydrological recharge to the pool allows the water level to remain relatively stable and not exhaust the water volume during the commercial life of the power plant.

A plant operating under Mode 2 (using the water once before returning it to the mine pool) consumes no water. Mode 2 assumes that the mine pool is a heat sink and that the volume of the mine pool is large enough to allow the heated water to cool through mixing and geothermal cooling before it is withdrawn again by the power plant.

The makeup water requirements of a closed-cycle cooling system are much smaller than either the once-through volume or the total recirculating volume. Typical makeup requirements for freshwater cooling towers are about $2 \%$ to $3 \%$ of the total recirculating water flow in a closedcycle systems although some values may be higher or lower than this range. ${ }^{13}$ Using the regression equation from Figure 3-6, a hypothetical 400-MW, coal-fired power plant with a wet cooling tower would require about 200,000 gpm (288 MGD) of circulating water. The makeup water flow (Mode 3) for this size of system should range from about 4,000 to 6,000 gpm (6 MGD to 8.6 MGD), depending on the quality of the water and the number of cycles of concentration used in the cooling system. Generally, freshwater systems can tolerate a larger number of cycles of concentrations than salt or brackish water. This reduces the volume of makeup water needed. However, mine pool water may have a greater concentration of dissolved solids or other constituents than typical freshwater systems, and therefore may require a lower number of cycles of concentration and a higher flow rate of makeup water.

The regression curves developed and shown in Figure 3-6 represent mostly large commercial power plants. They may not be representative for small, regional facilities. To demonstrate this point, Figure 3-7 plots flow versus capacity data for six small cogeneration plants located in the anthracite region of Pennsylvania that are already using mine pool water as makeup for their closed-cycle cooling systems. The data, which range from about 2 to $24 \mathrm{gpm} / \mathrm{MW}$, do not follow any obvious pattern, and no meaningful regression line can be drawn. Nevertheless, these data give an indication of the range of flow rates needed by small facilities.

A plant operating under Mode 4 will use no mine pool water. Like Mode 2, Mode 4 operates under the assumption that the mine pool is a heat sink. While Mode 2 will induce mixing through the turbulent flow of the discharge stream into the mine pool, Mode 4 has no discharge, and therefore no mechanism to induce active mixing. There will be some passive mixing caused by convection from the warm tubing walls. The dissipation of heat from the tubing near-field must be sufficiently large and the length of the cooling loop must be sufficiently long so that the fluid can be cooled enough to meet the condenser cooling load on the next pass.

\footnotetext{
${ }^{13}$ Zammit, K., 2003, personal communication from Zammit (Electric Power Research Institute) to J.A. Veil (Argonne National Laboratory), on September 17.
} 


\subsection{Water Quality}

Many of the coal-fired plants in the eastern part of the United States use untreated ambient water withdrawn from the rivers adjacent or near to the generating facility. ${ }^{14}$ Most of the water utilized for once-through or closed-cycle cooling passes through the plant's intake screen and is cycled once through the condenser or in the case of cooling towers, 3 to 5 times before cooling tower blow down. The power plants control scaling and biological deposition by the addition of chemicals into the cooling water.

Some of the typical problems associated with cooling water on the operation of a once-through or closed-cycle power plant cooling system include:

- Deposit Formation - This would include scaling, which is defined as the deposition of a mineral (for example, $\mathrm{CaCO}_{3}$ ) on the surface of heat transfer systems. Another form of deposit formation is fouling. Fouling can be characterized as the deposition and accumulation of suspended solids (for example, precipitation of ferric iron) in the cooling water system.

- Corrosion - The efficiency and operation of cooling water systems and subsystems can be affected by deterioration of metal surfaces. Corrosion can occur either chemically (low $\mathrm{pH}$ ) or electrochemically (galvanic corrosion).

- Biological - Microorganisms can grow and accumulate in the cooling water system. Certain bacteria, such as crenothrix bacteria, feed on iron that may be present in a plant's cooling water.

Treatment of water for boiler water makeup is another issue. It is critical that pure water is used for the steam cycle. This high-purity water is necessary in order to prevent the build-up of scale and deposits in boiler tubes, the turbine generator, and to prevent corrosion. Typical water influent requirements for boiler water and sub-critical (operating) units are listed in Table 3-1.

From a cooling perspective, power plants operate more efficiently when the incoming cooling water temperature is low. Mine pool water is desirable because it has a relatively consistent and low temperature year round. In situations where mine pool water will be used only as a seasonal water supply, the time of year when it is most likely to be used is during summer, low-flow periods. The cool mine pool water will be an effective cooling medium compared to the warmer surface waters that otherwise would be used.

\footnotetext{
${ }^{14}$ Wood, A., 2003, personal communication from Wood (American Electric Power) to J.M. Kupar (Argonne National Laboratory).
} 


\section{Table 3-1: Typical Water Influent Requirement for Boilers at Power Generating} Facilities $^{15}$

\begin{tabular}{|l|c|}
\hline \multicolumn{1}{|c|}{ Criterion } & Limit \\
\hline Total Suspended Solids & $<25 \mathrm{ppb}$ \\
\hline Dissolved Oxygen & $10-20 \mathrm{ppb}$ \\
\hline $\mathrm{pH}$ & $8-10 \mathrm{ppb}$ \\
\hline Phosphate & $1-5 \mathrm{ppb}$ \\
\hline Specific Conductivity & $15-30 \mathrm{mmho}$ \\
\hline Free Hydroxide & $0 \mathrm{ppm}$ \\
\hline Silica (dependent on pressure) & $<9 \mathrm{ppm}$ \\
\hline Chlorides (dependent on pressure) & $<4 \mathrm{ppm}$ \\
\hline Sulfates (dependent on pressure) & $<4 \mathrm{ppm}$ \\
\hline
\end{tabular}

\subsection{Water Treatment of Mine Pool Water}

Section 2.6 of this paper presents the general nature and quality of mine pool water in the bituminous coal fields of western Pennsylvania and West Virginia and the anthracite coal fields of eastern Pennsylvania. The mine pool water generally exhibits elevated levels of total dissolved solids (TDS), hardness, acidity and a bimodal frequency distribution of $\mathrm{pH}$ with nodes of $\mathrm{pH} 2.5$ to 4 and $\mathrm{pH} 6$ to 7.

In light of the elevated levels of TDS, hardness, and the variable nature of $\mathrm{pH}$, the majority of mine pool water will have to be treated to some degree, prior to use in a power plant's cooling water system. Treatment technologies for $\mathrm{pH}$ adjustment, removal of TDS, dissolved metal ions, and variables found in mine pool water are well established.

An example of a treatment system that might be used for the treatment of mine pool water for a closed-cycle cooling system makeup includes the following process units.

- Clarification to remove settleable solids

- $\mathrm{pH}$ adjustment, horizontal precipitator, coagulation, and flocculation for metals removal

- Multimedia filtration, ion exchange, and carbon adsorption if necessary to remove low TDS

Any water that will be used for boiler feed water will require additional treatment. The following additional treatment units can produce high-quality boiler feed water.

- Cartridge filter units for additional sub-micron particle removal

- Reverse osmosis and/or ion exchange for additional polishing

\footnotetext{
${ }^{15}$ Wood, Alan, 2003, email communication from Wood (American Electric Power) to J.M. Kupar (Argonne National Laboratory).
} 


\section{Chapter 4 - Siting Considerations and Transportation Issues}

Siting decisions for power plants must consider many factors. In addition to the proximity to fuel supply, transmission lines, and ash disposal, securing a dependable and adequate water supply, especially when the local municipal system lacks the capacity or charges high fees, plays a critical role. The ideal candidate power plant for using mine pool water would be built within a relatively short distance from the mine pool. This may not be practical, however. Many coal mines are located in rugged terrain. The most desirable location for a hypothetical power plant may be very distant from an underground mine site. If the selected site lacks sufficient water resources but is otherwise a good candidate, project sponsors may consider transporting mine pool water over long distances from the mine(s) to the power plant.

\subsection{Siting Considerations}

Critical factors that are evaluated when determining the appropriate location for a power plant that wishes to utilize mine pool water for cooling applications include the quality, quantity, and sustainability of the resource. ${ }^{16}$ The location must have access to a mine pool resource that meets the acceptable criteria for each factor.

\subsubsection{Water Quality}

The quality of the water resources will directly affect the costs associated with the treatment of the water to meet cooling system influent requirements, boiler feed water (if applicable), as well as the operations and maintenance of the system. The $\mathrm{pH}$, hardness, mineral content, and suspended solids are but a few of the variables that will affect the cost of the treatment system. The quality of the water may also affect the materials of construction for both the water treatment system and sub-system components of the power plants cooling system (such as piping, heat exchangers, and pumps).

Within the anthracite region of eastern Pennsylvania and the bituminous fields of western Pennsylvania and West Virginia, the quality of mine pool water can vary among adjacent mines and coal seams. Therefore, as an important siting criterion, the power plant should be located near a mine pool or several mine pools exhibiting a water quality close to the cooling system's influent requirements or amenable to economical treatment.

\subsubsection{Water Quantity}

Closed-cycle and once-through cooling systems will require a minimum flow for optimal cooling efficiency at the power plant. Another important siting criterion relates to the identification of a mine pool or a series of pools that can maintain the required flow of water through the cooling system, especially during sustained peak load periods.

\footnotetext{
${ }^{16}$ Burris, Kenneth, 2003, personal communication from Burris (UAI Environmental, Inc., Consultant to GenPower, LLC) to J.M. Kupar (Argonne National Laboratory).
} 


\subsubsection{Sustainability}

The third criterion for consideration when determining the location of a power plant that will utilize mine pool water for cooling and process use relates to the ability of the mine pool or combined mine pools to sustain this resource over the life of the power plant. Power plants typically have a useful life of several decades. Therefore, it is important that the draw on this resource can be sustained over the life of the facility. The sustainability of the mine pool water resource depends on the recharge of the mine pool and the local or regional infiltration of precipitation.

Long-term operation of a power plant requires a large cumulative volume of water. Table 4-1 shows the volume of water needed over 20,30,40, and 50 years using the flow estimates reported in Chapter 3. The volume needed for a $400-\mathrm{MW}$ plant using once-through cooling (Mode 1) is significant (nearly 7 trillion gallons over 50 years). Such a large volume may exceed the capacity of a mine pool to supply the plant's full cooling water needs; however, mine pool water could contribute a portion of the plant's water needs. Mine pool water can play an important role at times of the year when surface water bodies are experiencing low flow conditions and are otherwise not available for plant withdrawal. The volume of water estimated by the NMRC study (see Section 2.3.2) as being available in 130 mines in West Virginia and western Pennsylvania (250 billion gallons) would easily accommodate the cooling needs of a $400-\mathrm{MW}$ power plant operating under mode 3 conditions.

Table 4-1: Estimated Flow Volume Required for Life Span of Power Plant

\begin{tabular}{|c|c|c|c|c|c|}
\hline \multirow[t]{2}{*}{ Type of Facility } & \multirow{2}{*}{$\begin{array}{l}\text { Flow } \\
\text { Rate } \\
\text { (gpm) }\end{array}$} & \multicolumn{4}{|c|}{$\begin{array}{l}\text { Total Volume for Life Span of Plant (million gallons and } \\
\text { [acre-feet]) }\end{array}$} \\
\hline & & 20 years & 30 years & 40 years & 50 years \\
\hline $\begin{array}{l}\text { 400-MW Plant } \\
\text { (Mode 1) }\end{array}$ & $254,000^{*}$ & $\begin{array}{l}2,670,000 \\
{[8,197,000]}\end{array}$ & $\begin{array}{l}4,005,000 \\
{[12,295,000]}\end{array}$ & \begin{tabular}{|l|}
$5,340,000$ \\
{$[16,400,000]$}
\end{tabular} & \begin{tabular}{|l|}
$6,680,000$ \\
{$[20,490,000]$}
\end{tabular} \\
\hline $\begin{array}{l}\text { 400-MW Plant } \\
\text { (Mode 3-2\% } \\
\text { makeup) }\end{array}$ & $4,000^{*}$ & $\begin{array}{l}42,000 \\
{[129,000]}\end{array}$ & $\begin{array}{l}63,000 \\
{[193,000]}\end{array}$ & $\begin{array}{l}84,000 \\
{[258,000]}\end{array}$ & $\begin{array}{l}105,000 \\
{[322,000]}\end{array}$ \\
\hline $\begin{array}{l}\text { 400-MW Plant } \\
\text { (Mode 3-3\% } \\
\text { makeup) }\end{array}$ & $6,000^{*}$ & $\begin{array}{l}63,100 \\
{[193,600]}\end{array}$ & $\begin{array}{l}94,600 \\
{[290,000]}\end{array}$ & $\begin{array}{l}126,000 \\
{[388,000]}\end{array}$ & $\begin{array}{l}157,000 \\
{[480,000]}\end{array}$ \\
\hline $\begin{array}{l}\text { Small } \\
\text { Cogeneration Plant } \\
\text { (Mode 3-low end } \\
\text { of flow range) }\end{array}$ & $100^{* *}$ & $\begin{array}{l}1,050 \\
{[3,230]}\end{array}$ & $\begin{array}{l}1,580 \\
{[4,800]}\end{array}$ & $\begin{array}{l}2,100 \\
{[6,450]}\end{array}$ & $\begin{array}{l}2,600 \\
{[8,100]}\end{array}$ \\
\hline $\begin{array}{l}\text { Small } \\
\text { Cogeneration Plant } \\
\text { (Mode 3-high end } \\
\text { of flow range) }\end{array}$ & $1,100^{* *}$ & $\begin{array}{l}11,600 \\
{[35,500]}\end{array}$ & $\begin{array}{l}17,300 \\
{[53,200]}\end{array}$ & $\begin{array}{l}23,100 \\
{[71,000]}\end{array}$ & \begin{tabular}{|l|}
28,900 \\
{$[89,000]$}
\end{tabular} \\
\hline
\end{tabular}

* Flow rate from Section 3.4.

** Flow rate from Section 5.1. 


\subsection{Transportation Issues}

\subsubsection{Piping}

The most obvious transportation means is a pipeline with associated pumping stations that would convey the water to the plant. Modern engineering methods can pipe high volumes of fluids over large distances. For example, the Trans Alaska pipeline moves more than 40 MGD of crude oil over more than 800 miles from Alaska's North Slope to the port facilities in Valdez. The pipeline passes through rough terrain and experiences very cold temperatures during much of the year. (More information on the pipeline is available at $<\underline{\mathrm{http}} / / / \operatorname{tapseis.anl.gov}>$.) Since some mine pool water is acidic, the materials used for the piping and pumps must be compatible with the mine pool water.

But even though the technology and capability to construct a pipeline exists, there may be circumstances under which construction of such a pipe would involve unacceptable costs or face permitting challenges, such as the need to obtain a wetlands permit or secure rights-of-way to traverse someone's property.

\subsubsection{The Stream As a Conduit}

If mine pool water is used under Mode 5, it may be necessary to treat the mine pool water so that water discharge requirements can be met. The extent and cost of treatment will depend on the specific quality of the water from each mine. Such treatment could be costly because substantial volumes of water are involved. It is assumed that the power company will bear the treatment costs and that such costs will be lower than those associated with building a pipeline or arranging for an alternate source of water. At specific mine pool locations where overflow is imminent, local and state agencies may be willing to work with downstream users to share the cost of treatment and avoid or minimize significant environmental degradation caused by overflowing mine pools. 


\section{Chapter 5 - Current Use of Mine Pool Water by Power Plants}

Although the use of mine pool water for power plant cooling has not been practiced widely, at least six small power plants in the anthracite region of Pennsylvania have been using mine pool water for over a decade. Chapter 5 describes these facilities and also offers information about three other examples of mine pool water use that are either in a trial phase or are planned.

\subsection{Small Plants in the Anthracite Region}

Anthracite has been mined for many years in this region through underground mines. The rock and coal residues that were left behind after the anthracite was removed are known as culm. The culm has a caloric value and is used as a fuel by some small power plants in the region. At least six such plants use mine pool water as a cooling source. Table 5-1 provides a summary of the characteristics of those six plants. Five of the six plants operate on a closed-cycle cooling system and use the mine pool water as makeup water for the cooling system (Mode 3). Some also use the water for boiler feed and other plant water. The Northeastern Power Company uses an air-cooled condenser (also known as a dry cooling tower) for its main cooling source but has a small auxiliary wet cooling tower. Typically, circulating fluidized-bed boiler technology is used to produce steam for power generation. The rated capacity of the plants range from $31 \mathrm{MW}$ to $83 \mathrm{MW}$. The rate of mine pool water used for process cooling (cooling towers) and boiler water make-up range from 100 to $1,100 \mathrm{gpm}$.

Additional aspects of these plants are briefly mentioned in other sections of this report as they are relevant to the topics in those sections. None of the plants are using large quantities of mine pool water compared to the water requirements of a full-sized commercial unit, but they are reliant on the mine pool water to economically meet their water needs at those particular locations.

\subsection{Exelon's Limerick Plant}

Exelon Corporation owns and operates the Limerick nuclear power plant, located in southeastern Pennsylvania. The plant currently uses about 35 MGD of water during the summer months. During part of the year, the water is withdrawn from the nearby Schuylkill River, but the plant uses water piped many miles from the Delaware River during the rest of the year. Exelon looked for an alternative to using the Delaware River water and decided to seek permission to use water from the Wadesville Mine, an active coal mine located more than 70 miles upstream from the plant. Water from the Wadesville Mine is not as acidic as the water from many other mines, thereby allowing for its discharge without treatment to a local stream that eventually feeds into the Schuylkill River. On July 8, 2003, the online version of the Philadelphia Inquirer included an article describing the impending use of mine pool water by the Limerick nuclear power plant in southeastern Pennsylvania. (See http://www.philly.com/mld/philly/news/local/6253550.

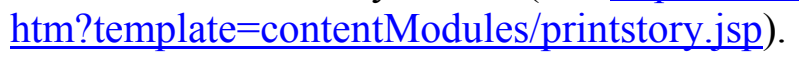


Table 5-1: Characteristics of Six Plants in Anthracite Region Currently Using Mine Pool Water

\begin{tabular}{|c|c|c|c|c|c|c|c|c|}
\hline $\begin{array}{l}\text { Company } \\
\text { Name }\end{array}$ & $\begin{array}{l}\text { Plant } \\
\text { Location }\end{array}$ & $\begin{array}{l}\text { Generating } \\
\text { Capacity }\end{array}$ & $\begin{array}{l}\text { Source of } \\
\text { Cooling } \\
\text { Water }\end{array}$ & $\begin{array}{l}\text { Withdrawal } \\
\text { Rate }\end{array}$ & $\begin{array}{l}\text { Distance } \\
\text { from } \\
\text { Mine } \\
\text { Pool to } \\
\text { Plant } \\
\end{array}$ & $\begin{array}{l}\text { Length of } \\
\text { Time } \\
\text { Using } \\
\text { Mine Pool } \\
\text { Water } \\
\end{array}$ & Comments & $\begin{array}{l}\text { Company } \\
\text { Contact }\end{array}$ \\
\hline $\begin{array}{l}\text { Gilberton } \\
\text { Power } \\
\text { Company }\end{array}$ & $\begin{array}{l}\text { Frackville, } \\
\text { PA }\end{array}$ & $80 \mathrm{MW}$ & $\begin{array}{l}\text { Unnamed } \\
\text { mine pool }\end{array}$ & $\begin{array}{l}\text { - } 833 \text { gpm } \\
\text { - } 1,500 \text { gpm } \\
\text { (pump } \\
\text { capacity) } \\
\text { - 500 } \\
\text { MG/year }\end{array}$ & $\begin{array}{l}\text { - } 1.5 \text { miles } \\
\text { - change } \\
\text { in } \\
\text { elevation } \\
\text { of } 550- \\
600 \text { feet }\end{array}$ & $>15$ years & $\begin{array}{l}\text { need a treatment system } \\
(\$ 0.16 / 1,000 \mathrm{gal})\end{array}$ & $\begin{array}{l}\text { Jim Weaver, } \\
570-874- \\
4456, x 421\end{array}$ \\
\hline $\begin{array}{l}\text { Northeastern } \\
\text { Power } \\
\text { Company }\end{array}$ & $\begin{array}{l}\text { McAdoo, } \\
\text { PA }\end{array}$ & $50 \mathrm{MW}$ & $\begin{array}{l}\text { Drainage } \\
\text { tunnel for } \\
\text { Silverbrook } \\
\text { mine }\end{array}$ & $100 \mathrm{gpm}$ & 3,000 feet & 14 years & $\begin{array}{l}\text { - water is used for auxiliary } \\
\text { cooling tower, boiler } \\
\text { makeup, and other plant } \\
\text { purposes } \\
\text { - need to treat }\end{array}$ & $\begin{array}{l}\text { Jim Wetzel, } \\
570-929- \\
3242\end{array}$ \\
\hline $\begin{array}{l}\text { Panther Creek } \\
\text { Generating } \\
\text { Station }\end{array}$ & $\begin{array}{l}\text { Nesque- } \\
\text { honing, PA }\end{array}$ & $83 \mathrm{MW}$ & $\begin{array}{l}\text { Lausanne } \\
\text { mine } \\
\text { tunnel }\end{array}$ & $\begin{array}{l}-764 \mathrm{gpm} \\
-1.1 \mathrm{MGD}\end{array}$ & $\begin{array}{l}5 \text { to } 6 \\
\text { miles }\end{array}$ & 11 years & $\begin{array}{l}\text { - need to treat } \\
\text { - pumping and treatment } \\
\text { costs are high }\end{array}$ & $\begin{array}{l}\text { Jim Carroll, } \\
570-645- \\
8721 \\
\end{array}$ \\
\hline $\begin{array}{l}\text { Schuylkill } \\
\text { Energy } \\
\text { Resources, } \\
\text { Inc. }\end{array}$ & $\begin{array}{l}\text { Shenan- } \\
\text { doah, PA }\end{array}$ & $80 \mathrm{MW}$ & $\begin{array}{l}\text { Maple Hill } \\
\text { mine }\end{array}$ & $1,100 \mathrm{gpm}$ & $3 / 4$ mile & 14 years & $\begin{array}{l}\text { - need to treat } \\
\text { - also can use potable water } \\
\text { or can blend the two sources }\end{array}$ & $\begin{array}{l}\text { Bob Boretski, } \\
570-462- \\
2822, x 25\end{array}$ \\
\hline $\begin{array}{l}\text { WPS - } \\
\text { Westwood } \\
\text { Generation } \\
\text { Plant }\end{array}$ & $\begin{array}{l}\text { Tremont, } \\
\text { PA }\end{array}$ & $31 \mathrm{MW}$ & $\begin{array}{l}\text { Lyken } \\
\text { mine }\end{array}$ & $800 \mathrm{gpm}$ & $<200$ feet & 17 years & $\begin{array}{l}\text { - have a backup well in } \\
\text { another mine pool with } \\
\text { worse water quality } \\
\text { - treatment costs } \sim \$ 75,000 \text { to } \\
100,000 \text { per year } \\
\text { - pay } \$ 0.14 / 1,000 \text { gal to } \\
\text { SRBC }\end{array}$ & $\begin{array}{l}\text { Jim Shuey, } \\
570-695- \\
3175\end{array}$ \\
\hline $\begin{array}{l}\text { Wheelabrator } \\
\text { Frackville } \\
\text { Energy Co. }\end{array}$ & $\begin{array}{l}\text { Frackville, } \\
\text { PA }\end{array}$ & $42 \mathrm{MW}$ & $\begin{array}{l}\text { Morea } \\
\text { mine }\end{array}$ & $600 \mathrm{gpm}$ & $<1$ mile & 15 years & - need to treat & $\begin{array}{l}\text { Ed Griegle, } \\
570-773- \\
0405\end{array}$ \\
\hline
\end{tabular}


Exelon plans a trial program during the summer and fall of 2003 in which the mine will discharge an additional 14.5 MGD for a limited period and the plant will withdraw that volume downstream. $^{17}$ At this time, Exelon does not know if the Wadesville Mine can sustain the higher level of discharge required for cooling at the Limerick/Exelon Plant over the long term. According to the Inquirer article, Exelon would also consider using water from contaminated mines in the future if this trial is successful.

\subsection{Proposed GenPower Facility}

One additional use of mine pool water for power plant cooling is planned for the western Pennsylvania/West Virginia border area. A power plant proposed by GenPower LLC will use mine pool water from the southwestern bituminous coal fields of Pennsylvania for cooling. GenPower's Longview Power Plant (previously known as the Robinson Run plant) would be located in Maidsville, West Virginia (northeast of Morgantown, West Virginia). The plant would have a rated generating capacity of $600 \mathrm{MW}$ and would utilize 7,000 gpm of mine pool water from the Shannopin mine as well as several other nearby mines in Greene County, Pennsylvania. The mine pool water would be extracted from the mines and treated at a central treatment facility near the Shannopin mine. Treated water would then be pumped six miles to the power generation facility at Maidsville. GenPower continues to move forward with permitting the facility, which received its draft air permit in August 2003.

\subsection{Waste Management and Processors, Inc. (WMPI PTY., LLC)}

The DOE's Clean Coal Initiative program has selected WMPI PTY., LLC to build a coal gasification plant in Frackville, Pennsylvania. The plant will utilize anthracite coal mining waste (culm) as feedstock in a gasification process to produce synthesis gas of carbon monoxide and hydrogen. The synthesis gas will be used to produce electric power and steam. A side stream of the synthesis gas will be used to produce synthetic hydrocarbon liquids (naphtha, kerosene, and diesel) by Fischer-Tropsch synthesis, which is a catalytic chemical process. The facility will convert 4,711 tons per day of anthracite culm into 5,038 barrels per day of fuel and produce 41 MW of power. The facility will use $7 \mathrm{MGD}$ or $4861 \mathrm{gpm}^{18}$ of mine pool water. The mine pool water will be obtained from the Gilberton mine pool. Construction of this facility is scheduled to begin in 2004.

\footnotetext{
${ }^{17}$ Sklenar, Scott, 2003, personal communication from S. Sklenar (Exelon Corporation) to J. Veil (Argonne National Laboratory).

${ }^{18}$ Hoppe, Robert, 2003, personal communication from R. Hoppe (Waste Management and Processors, Inc.[WMPI PTY., LLC.,]) to J. Kupar (Argonne National Laboratory).
} 


\section{Chapter 6 - Regulatory Issues}

Chapter 6 highlights regulatory issues posed by the use of mine pool water for power plant cooling. Because this is a new issue, the regulatory picture is still evolving. As discussions are unfolding, tailored opinions by counsel are generally not (yet) available. Regulators emphasize that all final determinations will be specific to each project. The following topical overview is intended to identify issues and, where possible, offer preliminary indications for some of the likely answers.

\subsection{Agencies with Regulatory Involvement}

In light of the different project phases and use scenarios as well as the fragmentation of environmental regulations, project implementation will require coordination with multiple agencies across different levels of government.

\subsubsection{Federal Agencies}

Federal laws are published in the United States Code (U.S.C.). The implementing regulations are codified in the Code of Federal Regulations (C.F.R.). The major federal agencies include the EPA, and the Office of Surface Mining (OSM) in the U.S. Department of the Interior (DOI).

\subsubsection{EPA}

The authorities and responsibilities of the EPA derive from the major environmental media statutes enacted in the 1970s, including the CWA (33 U.S.C. $§ 1251$ et seq.) and the Safe Drinking Water Act (SDWA) (42 U.S.C. $§ 300 \mathrm{f}$ et seq.). States have the option of applying for primary program responsibility or primacy. If a state does not obtain primacy, then the EPA implements the program directly through one of its regional offices. Pennsylvania and West Virginia have approved CWA National Pollutant Discharge Elimination System (NPDES) programs in place. NPDES permitting is relevant for the discharge of once-through cooling water into a stream, and the discharge into a stream that serves a conduit to transfer water from the mine to a downstream user. With respect to the SDWA Underground Injection Control (UIC) program, the EPA runs the program in direct implementation in Pennsylvania, whereas West Virginia has sought and obtained UIC program primacy. UIC requirements are relevant for returning the warm water to the mine pool.

None of the facilities surveyed (including the Panther Creek Generating Plant and the Limerick/Exelon Plant) had to undergo federal permitting, since they do not return the water into the mine pool. However, future projects may involve this regulatory scenario.

\subsubsection{OSM/DOI}

SMCRA (30 U.S.C. $§ 1201$ et seq.; 30 C.F.R. Parts 700-955) entrusted the OSM with writing nationwide mining rules. SMCRA established a reclamation program for abandoned mine lands, funded by fees on coal production, which provides for the restoration of eligible lands and waters 
mined and abandoned or left inadequately restored. SMCRA also gave OSM the authority to delegate the program to the states. Both Pennsylvania (30 C.F.R. § 938.10) and West Virginia (30 C.F.R. § 948.10) have obtained program primacy. The mining laws are also relevant for tracking ownership, control, access, and potential liabilities.

\subsubsection{State Regulatory Agencies}

The major state agencies include the Pennsylvania Department of Environmental Protection (PADEP) and the West Virginia Department of Environmental Protection (WVDEP).

\subsubsection{Pennsylvania}

The Pennsylvania Code (Pa. Code) contains Pennsylvania's rules and regulations administered by PADEP. Authority derives from the laws published in Pennsylvania Statutes (P.S.).

The PADEP Office of Water Management plans, directs and coordinates programs associated with the management and protection of the Commonwealth's water resources. It administers and oversees programs involving surface and groundwater quantity and quality planning. Moreover, it coordinates policies, procedures and regulations that influence public water supply withdrawals and quality, point source discharges, earth disturbance activities. The Office of Water Management includes the Bureau of Water Supply and Wastewater Management and the Bureau of Watershed Management.

- The Bureau of Water Supply and Wastewater Management (Division of Wastewater Management) runs the NPDES program. Contact: Parimal Parikh (717-783-8394 or pparikh@state.pa.us).

- The Bureau of Watershed Management (Division of Water Use Planning) manages the filing process for the metering, recording, and reporting of water withdrawals in Pennsylvania's portions of river basins pursuant to all applicable requirements. Contact: William Gast (717772-5671 orwgast@state.pa.us).

The PADEP Office for River Basin Cooperation coordinates the Commonwealth's responsibilities as a member to interstate river basin organizations and develops strategies for partnerships through interstate association.

- Contact: John Booser (717-772-1101 or jbooser@state.pa.us).

The PADEP Office of Mineral Resources Management administers and oversees the Abandoned Mine Reclamation Program in Pennsylvania. The Office of Mineral Resources Management includes the Bureau of Abandoned Mine Reclamation.

- The Bureau of Abandoned Mine Reclamation (Division of Acid Mine Drainage Abatement) is responsible for resolving problems such as mine subsidence and other hazards, and for 
abating or treating acid mine drainage from abandoned mines. Contact: Joseph Schueck (717-783-5633 or jschueck@state.pa.us).

In addition, the PADEP Secretary requested the Mining and Reclamation Advisory Board (MRAB) to form a task force to explore innovative approaches dealing with reuse and recycling of mine water as one alternative to treatment as well at to explore funding of long-term treatment. The MRAB responded by forming the Orphan Mine Discharge Task Force. The designation of orphan refers to those discharges, for which there is no responsible entity to provide treatment of the discharges and those discharges that do not have a funding mechanism in place to cover perpetual treatment.

- The goal of the Orphan Mine Discharge Task Force is to search for new ideas and methodologies for pollution prevention, innovative treatment, and recycling and reuse of the mine water. Contact: Joseph Schueck (717-783-5633 or jschueck@state.pa.us).

Finally, the Mid-Atlantic States regional office of the EPA (Region 3), headquartered in Philadelphia, is responsible for federal environmental programs in Pennsylvania.

- The Region's Safe Drinking Water Branch manages and implements the Region's underground injection control programs. This includes the direct implementation of the UIC program in Pennsylvania. Contact: Karen Johnson (215-814-5445 or johnson.karend@epa.gov); Steve Platt (215-814-5464 or steve.platt@epa.gov).

PADEP has reviewed several projects that involve the use of mine pool water for power plant cooling and other purposes. When facilities such as the Panther Creek Generating Plant do not have a discharge to surface waters, they do not require an NPDES permit. In the case of Exelon's Limerick Plant, which uses the Schuylkill River as a more than 70-mile natural pipeline or conduit to transport the mine pool water from the mine to the facility, the discharges into a stream that is a tributary to the Schuylkill River are covered by the NPDES already in place for the mine site.

\subsubsection{West Virginia}

The Code of State Regulations (C.S.R.) contains West Virginia's regulations administered by the WVDEP. Authority derives from the laws published in the West Virginia Code (W.Va. Code).

The WVDEP Division of Water and Waste Management implements programs controlling surface and groundwater pollution and solid and hazardous waste management. In addition, the Division is responsible for protecting, restoring, and enhancing West Virginia's watersheds. The Permitting and Engineering Branch of the Division of Water and Waste Management includes the Regulatory Section and the Permitting Section.

- The Regulatory Section oversees ground water protection and UIC. Contact: Dave Watkins (304-558-2108 or dwatkins@dep.state.wv.us). 
- The Permitting Section manages NPDES permitting program. Contact: Pravin Sangani (304558-4086 or psangani@dep.state.wv.us).

The WVDEP Division of Mining and Reclamation regulates the mining industry in West Virginia in accordance with federal and state law. The Division of Mining and Reclamation includes the Program Development Unit and the Special Reclamation Program.

- The Program Development Unit provides regulatory interpretation and develops policy and guidance to meet legal and regulatory requirements. Contact: Lewis Halstead (304-759-0510 or1halstead@mail.dep.state.wv.us).

- The Special Reclamation Program is responsible for land reclamation of unreclaimed areas to achieve the planned post-mining land use and water reclamation where problem discharges exist. Contact: Charles J. Miller(304-759-0521 or cmiller@mail.dep.state.wv.us).

WVDEP has reportedly not been involved in many actual projects that make use of mine pool waters. In one proposal, a power plant that wanted to use mine pool water could not secure access to the mine through the coal company and the proposal was withdrawn. A pending proposal involves a plant in West Virginia that would use water from a Western Pennsylvania mine in a project similar to the Limerick/Exelon scenario.

\subsubsection{Third States}

Third states enter the picture if project phases involve rivers at state borders, especially when a third state asserts rights to a river "from shore-to-shore." For example, Maryland controls the Potomac River along its border with West Virginia. The legal debate over control and jurisdiction may then very well involve royal charters, interstate compacts, and years of precedents (Jehl 2003).

\subsubsection{River Basin Commissions}

According to the federal Water Resources Planning Act (Public Law No. 89-80), a River Basin Commission serves as the principal agency coordinating federal, state, interstate, local and nongovernmental plans for the development of water and related land resources in its area, river basin, or group of river basins. It prepares and updates a comprehensive, coordinated, joint plan for federal, state, interstate, local and nongovernmental development of water and related resources. It recommends long-range schedules of priorities for the collection and analysis of basic data and for investigation, planning, and construction of projects.

Pennsylvania is a member of eight interstate organizations: the Chesapeake Bay Commission, the Delaware Estuary Program, the Delaware River Basin Commission (DRBC), the Great Lakes Commission, the Interstate Commission on the Potomac River Basin, the Ohio River Basin Commission, the Ohio River Valley Sanitation Commission (ORSANCO), and the Susquehanna River Basin Commission (SRBC). 
West Virginia is a member of the Interstate Commission on the Potomac River Basin, the Ohio River Basin Commission, and the Ohio River Valley Sanitation Commission (ORSANCO).

The regulatory authorities of the river basin commissions vary quite significantly. Some regulate surface and groundwater withdrawal operations (DRBC and SRBC), while others focus on water quality standards (ORSANCO) and information exchange (ORBC). Thus, the project location within a certain river basin can make a major difference with respect to scope of the applicable regulatory requirements. In broad terms, projects located in western Pennsylvania and West Virginia, as opposed to those in eastern Pennsylvania, are not subject to DRBC and SRBC regulation. In light of the varying regulatory authorities held by river basin commissions, it is important to determine which river basin commission will have jurisdiction for any proposed mine pool water projects.

The DRBC (18 C.F.R. $\S 401.35,430.1$ et seq.) and the SRBC (18 C.F.R. $\S 801,803.1$ et seq.) require approval of proposed surface and groundwater withdrawal activities having a significant effect on the water resources of the respective basins. The DRBC and the SRBC review only projects with high threshold quantities. In addition, the DRBC and the SRBC have the authority to designate Special Protection Areas and develop a comprehensive plan for water development use. ORSANCO has water quality standards, but no water withdrawal regulations in place. The DRBC imposes charges for consumptive and non-consumptive surface water withdrawals and stringent makeup requirements for consumptive usage. (In light of the DRBC's stringent makeup requirements for consumptive usage the power industry has established the Merrill Creek Reservoir in New Jersey.) The charges levied by the SRBC are more than twice as high and apply to both groundwater and surface water withdrawals, however the makeup requirements for consumptive use are not as stringent as those imposed by the DRBC. (Case examples of withdrawal costs charged by the DRBC and SRBC are provided below in Section 6.1.)

- The Delaware River is the longest undammed river east of the Mississippi. The river is fed by 216 tributaries, the largest being the Schuylkill and Lehigh Rivers in Pennsylvania. In all, the basin contains 13,539 square miles. The Delaware drains 6,422 square miles in Eastern Pennsylvania. The Pennsylvania drainage area corresponds to 50.3 percent of the Delaware River Basin's total land area. Contacts: Thomas Brand, DRBC (609-883-9500-ext. 221 or tbrand@drbc.state.nj.us).

- The six subbasins of the Susquehanna River Basin (Chemung, West Branch Susquehanna, Juniata, Upper Susquehanna, Middle Susquehanna, and Power Susquehanna) cover most of Eastern and Central Pennsylvania. Contacts: Todd Hitz, SRBC (717-238-0422-ext. 220 or thitz@srbc.net) or Glen DeWillie, SRBC (717-2380422-ext. 0 or gdewillie@srbc.net).

- The drainage area of the Ohio River Basin includes two counties in western Pennsylvania (Beaver and Allegheny) and the string of 12 counties at the western border of West Virginia. Contact: Jerry Schulte, ORSANCO (513-231-7719 or jschulte@orsanco.org). 
The surveyed projects, including the Limerick/Exelon Mine Pool Withdrawal and Stream Flow Augmentation Demonstration Project, had to secure water allocation permits or other approval from the DRBC and the SRBC. The facilities incur the applicable fees in the context of their withdrawal operations.

\subsubsection{Local Agencies}

For drilling operations other than underground injection, local authorities may need to be involved. For example, in West Virginia, anybody who drills a hole for a heat pump type of system must not only be a certified well driller (47 C.S.R. Series 59 and 60) but also comply with all applicable permitting and/or notification requirements imposed by the local health department in the county of operations. West Virginia has 55 counties.

Few local townships have municipal groundwater regulations in place (for example, zoning ordinances that contain standards based on low flow of streams). In Pennsylvania, for example, the Municipalities Planning Code (53 P.S. § 101 et seq.) includes language that townships plan and zone in a way to protect groundwater supplies and aquifers. Municipal groundwater regulation through zoning is limited (excluded or preempted) by federal, state, and interstate compact law.

\subsection{Withdrawal of Mine Pool Water}

\subsubsection{Who Owns Water before Withdrawal and after Withdrawal?}

Generally questions of ownership and control of subsurface resources seem more defined in the western states. In the eastern states the issue has just begun to appear on the radar screens. ${ }^{19}$

Pennsylvania's groundwater law is based on the so-called American Rule, which stems from the era of the Industrial Revolution and provides that a landowner may withdraw groundwater from beneath the property for "natural and ordinary" usage, whereas extraction for use off-site is "unreasonable" and "unlawful" (Penn State 1997). In light of the benefits associated with the withdrawal, treatment, and use of the mine pool water, PADEP is exploring innovative resolutions to the ownership issues raised when a project operator has not previously purchased the land. ${ }^{20}$ Several important questions have been formulated in this vein. Can someone who treats polluted mine water and develops it as a useful public and private water supply rely on the exercise of dominion over the water supply as a conclusive resolution of the ownership issue? How will the "capture rule" and common law, as modified by the Pennsylvania Water Rights Act of 1939 (32 P.S. § 631 et seq.), affect the ability to treat and use the mine pools and discharges?

\footnotetext{
${ }^{19}$ Miller, Charles, 2003, personal communication from C. Miller (West Virginia Department of Environmental Protection, Division of Mining and Reclamation, Special Reclamation Program) to M.G. Puder (Argonne National Laboratory).

${ }^{20}$ Roda, Marc, 2003, personal communications from M. Roda (Pennsylvania Department of Environmental Protection, Office of General Counsel) to M.G. Puder (Argonne National Laboratory).
} 
Does it make a legal difference if the industrial use operations occur on-land or off-land? PADEP will request legal opinions on ownership of mine water. ${ }^{21}$

In West Virginia, state officials recommend that project operators investigate who owns the surface land (tax maps), who owns the mineral rights, and who holds active SMRCA and NPDES permits to mine on this land. ${ }^{22}$ West Virginia regulators note that anybody who mines a coal seam becomes liable for the water. Any holder of an active permit will therefore be interested in safeguarding against additional potential liabilities triggered by activities of the third-party project operator. In West Virginia, the WVDEP Division of Mining and Reclamation tracks ownership and control.

\subsubsection{Are Any Permits or Approvals Required?}

PADEP does not regulate the amount of the mine pool water withdrawn. PADEP allocates only public suppliers of surface waters and regards the mine pools as groundwater. Groundwater includes all water from dug, drilled, bored, jetted, or driven wells and infiltration galleries, as well as springs that emerge at the surface within the confines of a springhouse.

Pennsylvania’s Water Resources Planning Act of 2002 (27 P.S. § 3101 et seq.), which provides for registration of major groundwater and surface water withdrawals (exceeding 10,000 gallons per day) and periodic reporting of water usage by such major users, is a planning law only. It does not give PADEP any additional authority to regulate, control, or require permits for the withdrawal or use of ground water and surface water. The registration requirement may be satisfied by reports submitted under other laws and regulations. (For example, similar reporting is in place with river basin commissions, and the PADEP will coordinate with these bodies to avoid duplication.)

Like PADEP, WVDEP does not regulate the amount of the mine pool water withdrawn. ${ }^{23}$

Groundwater and surface water withdrawals in the Delaware River Basin greater than 100,000 gallons per day and groundwater withdrawals greater than 10,000 gallons per day in the Southeastern Pennsylvania Groundwater Protected Area require review and approval by the DRBC. DRBC officials note that the difference between the definition of surface water and

\footnotetext{
${ }^{21}$ Schueck, Joseph, 2003, personal communications from J. Schueck (Pennsylvania Department of Environmental Protection, Office of Mineral Resources Management, Bureau of Abandoned Mine Reclamation, Division of Acid Mine Drainage Abatement) to M.G. Puder (Argonne National Laboratory).

${ }^{22}$ Miller, Charles, 2003, personal communication from C. Miller (West Virginia Department of Environmental Protection, Division of Mining and Reclamation, Special Reclamation Program) to M.G. Puder (Argonne National Laboratory); Halstead, Lewis, 2003, personal communication from L. Halstead (West Virginia Department of Environmental Protection, Division of Mining and Reclamation, Program Development Unit) to M.G. Puder (Argonne National Laboratory).

${ }^{23}$ Watkins, Dave, 2003, personal communication from D. Watkins (West Virginia Department of Environmental Protection, Division of Water and Waste Management, Permitting and Engineering Branch, Regulatory Section) to M.G. Puder (Argonne National Laboratory).
} 
groundwater is not always straightforward in light of the basin's "pooled water concept." A specific determination would be linked to the potential for surface water impacts. ${ }^{24}$ The DRBC considers withdrawals from mine pools as surface water withdrawals. For example, the DRBC considers withdrawal from the Lausanne Mine Pool by the Panther Creek Generating Plant surface water withdrawal in light of the "effect" of the operation. For the Susquehanna River Basin, the SRBC reviews and approves groundwater withdrawals greater than 20,000 gallons per day for projects resulting in consumptive use of water and 100,000 gallons per day for other projects. Diversion from the basin would be considered consumptive use of groundwater, and must comply with all applicable compensation requirements. ${ }^{25}$ The DRBC and the SRBC require metering, recording, and reporting with respect to withdrawal operations.

\subsubsection{Potential Liability for Subsidence and Interference with Existing Water Sources}

Under the mining laws of Pennsylvania and West Virginia, a mine operator must repair or compensate subsidence damage to certain structures, and restore and replace water supplies contaminated, diminished, or interrupted by underground mining.

In all likelihood, the project operator withdrawing the mine pool water presently will be a different entity from the company that originally mined the site, and in some instances, the withdrawal will occur a long time after mine abandonment. There is some dispute about liability for groundwater withdrawals under the American Rule applicable in Pennsylvania (Penn State 1997). Some courts have found that the impacting user is liable for damages when the withdrawal interferes with other users. Others have stated that liability is triggered only if the withdrawal is malicious or negligent. PADEP has not yet faced this situation and therefore has not conducted a detailed regulatory analysis relative to potential third-party interference issues (withdrawal of "polluted" mine pool water and recharge with "clean" groundwater diverted from localities supplying drinking water or private well owners). Since owners and users of impacted structures and private wells and springs may sue if their usage is disturbed by invasive mine pool water withdrawal operations, project operators should investigate potentially affected third-party water supplies. ${ }^{26}$

Pennsylvania's Environmental Good Samaritan Act (27 P.S. $§ 8101$ et seq.) encourages landowners and others to reclaim abandoned mineral extraction lands and abate water pollution caused by abandoned mines (PADEP Fact Sheet 2000). It protects landowners, groups, and individuals who conduct such projects from civil and environmental liability. Eligible water pollution projects are those that treat or stop water pollution caused by abandoned mines. The proposal must be approved by the PADEP. In support of proposals involving the use of mine

\footnotetext{
${ }^{24}$ Brand, Thomas, 2003, personal communication from T. Brand (Delaware River Basin Commission) to M.G. Puder (Argonne National Laboratory).

${ }^{25}$ Hitz, Todd, 2003, personal communication from T. Hitz (Susquehanna River Basin Commission) to M.G. Puder (Argonne National Laboratory).

${ }^{26}$ Roda, Marc, 2003, personal communications from M. Roda (Pennsylvania Department of Environmental Protection, Office of General Counsel) to M.G. Puder (Argonne National Laboratory).
} 
pool water, project operators may want to explain that they abate a nuisance by removing the polluted mine pool water and subjecting it to a treatment module. However, it should be noted that Pennsylvania's Environmental Good Samaritan Act provides protection under state law only and does not cover federal law. Moreover, the PADEP determines project eligibility, as opposed to making legal rulings reserved for the court system. If a project operator is sued, project approval should be used as a defense.

In contrast to Pennsylvania, West Virginia does not offer a Good Samaritan scheme. However, WVDEP officials note that they will exercise the appropriate regulatory discretion to accommodate projects that benefit economic interests, while being protective of the environment. $^{27}$

\subsection{Discharge of Once-Through Cooling Water}

If a power plant discharges once-through cooling water to a surface water body, the discharge must be authorized through an NPDES permit. NPDES permits control water pollution by regulating point sources that discharge pollutants into waters of the United States. Pollutant includes any type of waste discharged into water. The regulations group them into conventional, toxic, and non-conventional. Point sources are discrete conveyances such as pipes. Waters of the United States include navigable waters, tributaries to navigable waters, interstate waters, and certain intrastate lakes, rivers, and estuaries. The major components of an NPDES permit are the cover page, the effluent limits based on applicable technology-based and water quality-based standards, monitoring and reporting requirements, special conditions developed to supplement the effluent limits such as best management practices and toxicity reduction evaluations, and standard conditions. On the federal level, which serves as the blueprint for state programs, the EPA has established effluent limitations guidelines and new source performance standards for major industrial categories, including those for the coal mining industry (40 C.F.R. Part 434) and the steam electric power-generating category (40 C.F.R. Part 423). The requirements are developed based on the application of process or treatment technologies to control pollutant discharges.

\subsubsection{Is an NPDES Permit Required? Who Issues the Permit? What Are the Discharge Requirements?}

Pennsylvania and West Virginia require NPDES permits for point source discharges to a surface water body.

Pennsylvania's NPDES and water quality regulations have been codified at $25 \mathrm{~Pa}$. Code Chapters 92 and 93. In Pennsylvania, the permitting process will be administered by the

\footnotetext{
${ }^{27}$ Brannon, Bill, 2003, personal communication from B. Brannon (West Virginia Department of Environmental Protection, Division of Water and Waste Management, Executive Office) to M.G. Puder (Argonne National Laboratory); Watkins, Dave, 2003, personal communication from D. Watkins (West Virginia Department of Environmental Protection, Division of Water and Waste Management, Permitting and Engineering Branch, Regulatory Section) to M.G. Puder (Argonne National Laboratory).
} 
permitting section in the regional office for the county in which the discharge occurs. PADEP has six regional offices. Permitting will require extensive modeling. The discharge requirements will depend on numerous factors, including the discharge location, the stream classification, the flow condition of the stream, and the quantity and quality of the discharge. The mine pool water may contain metals of concern, including aluminum, iron, and manganese, and pose temperature concerns, especially when discharged after routing through a once-through cooling system. ${ }^{28}$ Zero dischargers do not need to secure an NPDES permit. For example, the Gilberton Power Company transfers its excess cooling tower blowdown to a coal processing plant that washes coal. The Northeastern Power Company captures the blowdown in a special tank prior to ash conditioning.

Pennsylvania's Orphan Mine Discharge Task Force will explore opportunities for alternatives to numeric effluent standards for certain discharges, especially those containing manganese. ${ }^{29}$ Potential alternatives must ensure that environmental values - for example, the use of surface water and the health of aquatic ecosystems - are not jeopardized by more cost-effective measurement or treatment.

West Virginia's regulations for its combined NPDES and water quality program have been codified at 47 C.S.R. Series 10. The WVDEP Division of Water and Waste Management Permitting Section issues the permits. Once-through cooling discharge operations have to meet technology-based requirements, water quality-based requirements, and antidegradation requirements. The permit writers would look to the EPA's effluent limitation guidelines for the steam electric power generating category. Where specific guidelines are not available, a best professional judgment standard is used. Water quality standards include temperature considerations. Depending on the specific stream, water quality standards will vary. For example, it may make a difference if the water body is a habitat for particularly sensitive fish species like trout; or if a municipal intake is located downstream. Antidegradation standards apply to new discharges, which are held not to cause significant impacts. ${ }^{30}$

If the surface water body were owned by a third state, then all applicable requirements imposed by that state must be met. In West Virginia, which owns the Ohio River at low-flow level, the

\footnotetext{
${ }^{28}$ Parikh, Parimal, 2003, personal communication from P. Parikh (Pennsylvania Department of Environmental Protection, Bureau of Water Supply and Wastewater Management, Division of Wastewater Management) to M.G. Puder (Argonne National Laboratory).

${ }^{29}$ Schueck, Joseph, 2003, personal communications from J. Schueck (Pennsylvania Department of Environmental Protection, Office of Mineral Resources Management, Bureau of Abandoned Mine Reclamation, Division of Acid Mine Drainage Abatement) to M.G. Puder (Argonne National Laboratory).

${ }^{30}$ Sangani, Previn, 2003, personal communication from P. Sangani (West Virginia Department of Environmental Protection, Division of Water and Waste Management, Permitting and Engineering Branch, Permitting Section) to M.G. Puder (Argonne National Laboratory).
} 
WVDEP Division of Water and Waste Management Permitting Section also forwards copies of draft permits to "affected" states. ${ }^{31}$

Interstate river commissions may enter the picture when it comes to reviewing state NPDES permit applications. For example, in the case of Pennsylvania, the DRBC reviews and approves certain discharges greater than 50,000 gallons per day. The SRBC conducts a permit review relative to potential interstate impacts and compliance with watershed restoration and protection efforts in the Susquehanna River Basin. ORSANCO sets pollution control standards, including wastewater discharge requirements. ${ }^{32}$ In this light, Pennsylvania and West Virginia coordinate draft permits with the relevant interstate river basin commissions.

\subsubsection{Opportunities for Trading or Special Relief}

Six cogeneration facilities in the anthracite region of Pennsylvania are currently using mine pool water and most have been using it for about 15 years. These facilities are paying a small fee to the DRBC or the SRBC to use the water. Although this appears to be the past and current way of handling mine pool withdrawals, there may be future situations in which users are compensated rather than having to pay to use the water. There are mine pools in other parts of Pennsylvania and in West Virginia that will overflow to streams or rivers in the near future and cause significant degradation of those water bodies. In such circumstances, the local communities, state or federal environmental agencies, or river basin commissions may offer incentives to potential water users to remove water from the mine pools, treat it, and use it for industrial purposes or discharge the treated water to the streams. Such incentives could take various forms, including tax credits, sharing of costs, and reduced monitoring or financial assurance requirements.

Environmental trading occurs between two entities when one entity sells a credit for better-thanrequired environmental performance to a second entity that uses the credit in lieu of directly meeting its own environmental performance requirements. For wastewater discharges from point and nonpoint sources, this type of trading is known as effluent trading. In January 1996, EPA released a policy statement endorsing effluent trading in watersheds, hoping to spur additional interest in the subject. To supplement the policy statement, EPA published a draft framework document that provides much more information on implementation of effluent trades (EPA 1996). Veil (1997; 1998) evaluated the opportunities for trading in the electric power industry and found that they were not great. In fact, nearly all of the early trading cases described in EPA (1996) involved trades of nutrient pollutants and not of toxics.

EPA recognized that trading has not flourished, and in 2001 began placing greater emphasis on developing new trading policies. Early in 2002, EPA circulated a new proposed water quality

\footnotetext{
${ }^{31}$ Sangani, Previn, 2003, personal communication from P. Sangani (West Virginia Department of Environmental Protection, Division of Water and Waste Management, Permitting and Engineering Branch, Permitting Section) to M.G. Puder (Argonne National Laboratory).

${ }^{32}$ Schulte, Jerry, 2003, personal communication from J. Schulte (Ohio River Valley Sanitation Commission) to M.G. Puder (Argonne National Laboratory).
} 
trading policy, and in early 2003 , the policy was finalized (see:

http://www.epa.gov/owow/watershed/trading/finalpolicy2003.pdf). The new policy embraces trading as a viable mechanism for achieving water quality goals. The proposed policy acknowledges that trades other than the traditional nutrient trades can occur on a case-by-case basis if the regulatory agencies concur with the trades. Further, it does not limit water trades to effluents, but rather refers to water quality trades. The policy would allow industrial, agricultural, and wastewater treatment plants and operations to meet their regulatory obligations by purchasing offsetting credits. Among eleven trading projects supported by the USEPA is an evaluation of the feasibility of reducing acid mine drainage in the Cheat River, WV. This stakeholder-driven effort assesses the potential for trading to achieve greater reductions in acid mine drainage pollution than would be achieved under current NPDES permits through actions to abate drainage from abandoned mines.

EPA's Office of Water is presently much more receptive to innovative water trading concepts than at any time in the past. The entire concept of trading water quality or even broader environmental benefits rather than trading pounds of pollutants is very new, and the science and policy surrounding the issue are still evolving. A recent report funded by the Electric Power Research Institute reviews a variety of environmental enhancement measures as well as some interesting approaches for using trading concepts as part of the process of mitigating environmental impacts associated with cooling water intake structures (EPRI 2003).

Remediation of contaminated mine pool water, either as part of a cooling water use scenario or as an unrelated mitigation offering by a power company, may be possible.

Pennsylvania has enacted the Environmental Good Samaritan Act to further such activities. ${ }^{33}$ Pennsylvania officials note that they have on their agenda the promotion of energy industries through the establishment of carbon trading credits. ${ }^{34}$ Other than trading in the area of total maximum daily loads, West Virginia has no special relief scheme in place. ${ }^{35}$

\subsection{Return of Warm Water to Mine Pool}

UIC programs provide safeguards so that injection operations do not endanger current and future underground sources of drinking water (USDWs). The UIC Program defines an injection well as any bored, drilled or a driven shaft or a dug hole, where the depth is greater than the largest surface dimension that is used to discharge fluids underground. For regulatory control purposes underground injection is grouped into five well classes. Class I wells are used for the

\footnotetext{
${ }^{33}$ Roda, Marc, 2003, personal communications from M. Roda (Pennsylvania Department of Environmental Protection, Office of General Counsel) to M.G. Puder (Argonne National Laboratory).

${ }^{34}$ Schueck, Joseph, 2003, personal communications from J. Schueck (Pennsylvania Department of Environmental Protection, Office of Mineral Resources Management, Bureau of Abandoned Mine Reclamation, Division of Acid Mine Drainage Abatement) to M.G. Puder (Argonne National Laboratory).

${ }^{35}$ Watkins, Dave, 2003, personal communication from D. Watkins (West Virginia Department of Environmental Protection, Division of Water and Waste Management, Permitting and Engineering Branch, Regulatory Section) to M.G. Puder (Argonne National Laboratory).
} 
emplacement of hazardous and nonhazardous fluids (industrial and municipal wastes) into isolated formations beneath the lowermost USDW. Class I operations are the most strictly regulated by the SDWA and are further controlled by the Resource, Conservation and Recovery Act. Class II wells inject brines and other fluids associated with oil and gas production. Class III wells inject fluids associated with solution-mining of minerals. Class IV wells, which involve the injection of hazardous or radioactive wastes into or above a USDW, are banned unless authorized under other statutes for ground water remediation. Class V wells include underground injection wells not included in Classes I through IV. Class V governs wells that inject nonhazardous fluids into or above a USDW. These wells are typically shallow, on-site disposal systems, such as floor and sink drains which discharge directly or indirectly to ground water, dry wells, leach fields, and similar types of drainage wells. UIC Class V requirements would be relevant for returning the warm water to the mine pool. However none of the facilities surveyed returns the water back to the mine pool.

\subsubsection{Is A UIC Permit or Other Approval Required? Who Issues the Permit?}

Since Pennsylvania does not have UIC program primacy, the Region 3 office of EPA administers UIC regulations through direct implementation. Region 3 would require a Class V rule authorization or permit for "cooling water" or "mine fill" wells, depending on the specific circumstances of the project. EPA Region 3 officials explain that the injection must not endanger USDWs. The returned water must meet drinking water standards, independent of whether the water withdrawn earlier met such standards. This means that the project operator might have to treat the water prior to returning the water into the mine pool. ${ }^{36}$

West Virginia's UIC regulations are available at 47 C.S.R. Series 13. West Virginia requires an individual UIC permit, which would be issued for Class V. Class V wells include cooling water return flow wells used to inject water previously used for cooling. Generally, Class V wells, which inject nonhazardous fluids into strata that contain underground sources of drinking water, must meet federal and state primary drinking water standards. However, if the reinjected water does not impact USDWs, and if the warm water returned to the mine is actually better that it was when withdrawn (for example, as a result of previous treatment), then regulators are willing to work with the project operator and offer relaxed standards. In West Virginia, the Regulatory Section of the Permitting and Engineering Branch of the Division of Water and Waste Management is responsible for West Virginia's UIC program. ${ }^{37}$

Pennsylvania and West Virginia do not allow injection back into the mine of water that is classified as a hazardous waste. Any hazardous waste has to be managed in accordance with all applicable hazardous waste management requirements. Project operators in Pennsylvania and

\footnotetext{
${ }^{36}$ Johnson, Karen, 2003, personal communication from K. Johnson (United States Environmental Protection Agency, Region 3, Safe Drinking Water Branch) to M.G. Puder (Argonne National Laboratory).

${ }^{37}$ Watkins, Dave, 2003, personal communication from D. Watkins (West Virginia Department of Environmental Protection, Division of Water and Waste Management, Permitting and Engineering Branch, Regulatory Section) to M.G. Puder (Argonne National Laboratory).
} 
West Virginia should therefore ensure that in the course of its use in the power plant, nothing is added to the water that makes it a hazardous waste.

\subsubsection{Are Any Permits Required For Use of Closed-Loop Heating Coil?}

This scenario poses no major regulatory hurdles in Pennsylvania and West Virginia, since this enclosed, self-contained, cyclic convection scenario involves neither discharge into a surface water body nor underground injection. ${ }^{38}$ EPA Region 3 officials emphasize that a leak in the system, however, would change the regulatory picture. ${ }^{39}$

\subsection{Zoning and Right-of-Way for Access to Mine Pool}

\subsubsection{Zoning}

Case law on zoning aspects of excessive water use has focused on the type of land use rather than on the quantity of water use. In general, municipalities may not zone out highly consumptive water uses, especially when covered by federal, state, and compact permits.

\subsubsection{Access Issues}

PADEP officials emphasize that easements or surface land rights may be needed to construct, use, and maintain the infrastructure needed to extract, treat, and distribute the water resources. In this light, PADEP is to request legal opinion on access rights. ${ }^{40}$

WVDEP officials recommend that project operators investigate who owns the surface land and who holds active SMRCA and NPDES permits to mine on this land.

\subsection{Transfer of Water from Mine to Downstream User - Use of Stream as Conduit}

This scenario involves discharge at the mining site and withdrawal downstream. This is particularly relevant if the water consumption at the downstream power plant is high. The Limerick/Exelon Plant involves this scenario, albeit on a trial-run basis. Mine pool water is pumped from the Wadesville Mine into the Norwegian Creek and then into the Schuylkill River,

\footnotetext{
38 Johnson, Karen, 2003, personal communication from K. Johnson (United States Environmental Protection Agency, Region 3, Safe Drinking Water Branch) to M.G. Puder (Argonne National Laboratory); Watkins, Dave, 2003, personal communication from D. Watkins (West Virginia Department of Environmental Protection, Division of Water and Waste Management, Permitting and Engineering Branch, Regulatory Section) to M.G. Puder (Argonne National Laboratory).

39 Johnson, Karen, 2003, personal communication from K. Johnson (United States Environmental Protection Agency, Region 3, Safe Drinking Water Branch) to M.G. Puder (Argonne National Laboratory).

${ }^{40}$ Roda, Marc, 2003, personal communications from M. Roda (Pennsylvania Department of Environmental Protection, Office of General Counsel) to M.G. Puder (Argonne National Laboratory).
} 
which serves as a more than 70-mile pipeline. A similar proposal is reportedly pending for a West Virginia plant.

\subsubsection{Discharge Requirements at Mine Site}

Pennsylvania and West Virginia require NPDES permits for discharges to a surface water body independent of the purpose of the activity. Pennsylvania and West Virginia would consider the transfer of polluted water into another water body as an addition of pollutants from a point source, even if nothing were added during the conveyance. ${ }^{41}$

Pennsylvania's permitting process would rely on the considerations described for the discharge of once-through cooling water. ${ }^{42}$ West Virginia would look to the EPA's effluent limitation guidelines for the coal mining industry.

In the case of the Limerick/Exelon Plant, the discharges into the stream are covered by the NPDES (PA0593508) already in place for the mine site. The numerical discharge limitations are: total suspended solids ( $35 \mathrm{mg} / 1$ average monthly, $70 \mathrm{mg} / 1$ maximum daily); total iron (3.5 mg/l average monthly, $7.0 \mathrm{mg} / 1$ maximum daily), manganese $(2.0 \mathrm{mg} / \mathrm{l}$ average monthly, $4.0 \mathrm{mg} / \mathrm{l}$ maximum daily), and $\mathrm{pH}$ range (6.0 to 9.0). The non-acidic mine pool water falls into the parameters of the existing permit. It goes into the stream untreated, at times mixed with water from a reservoir.

\subsubsection{Withdrawal Regulation Downstream}

Pennsylvania does not require a water appropriation permit for entities other than water allocation utilities. ${ }^{43}$ The Water Resources Planning Act of 2002 requires that certain water users register with PADEP the source, location and amount of water withdrawal and/or water use. This includes users of greater than 10,000 gallons per day from the same watershed. The law provides that this requirement may be satisfied by other reports submitted under certain statutes and regulations to the extent that the reports provide the required information.

In West Virginia, a water allocation permit for withdrawal of downstream water is not required. The state legislature contemplated but never enacted an authorizing law. West Virginia does not

\footnotetext{
${ }^{41}$ For recent litigation, see Miccosukee Tribe of Indians of Florida et al. v. South Florida Water Management District, No. 00-15703 (11 ${ }^{\text {th }}$ Cir. 2002) (addressing the South Florida Water Management District's Everglade's flood control operations, which involved the use of a pumping station to transfer water from canals with higher phosphorus levels into a receiving water basin).

${ }^{42}$ Parikh, Parimal, 2003, personal communication from P. Parikh (Pennsylvania Department of Environmental Protection, Bureau of Water Supply and Wastewater Management, Division of Wastewater Management) to M.G. Puder (Argonne National Laboratory).

${ }^{43}$ Booser, John, 2003, personal communication from J. Booser (Pennsylvania Department of Environmental Protection, Office for River Basin Cooperation, Division of Wastewater Management), to M.G. Puder (Argonne National Laboratory).
} 
have water quantity regulations in place. ${ }^{44}$ WVDEP officials point out that disproportionate withdrawal of water from smaller streams leading to low-flow conditions that interfere with waste load allocations for third party dischargers is not allowed.

Surface water withdrawals in the Delaware River Basin greater than 100,000 gallons per day require review and approval by the DRBC. The DRBC would not double-charge for water withdrawn from the mine, released into the stream, and captured downstream. ${ }^{45}$ For the Susquehanna River Basin, the SRBC reviews and approves surface water withdrawals greater than 20,000 gallons per day for projects resulting in consumptive use of water and 100,000 gallons per day for other projects. Diversion from the basin would be considered consumptive use of groundwater, and must comply with all applicable compensation requirements. ${ }^{46}$ The $\mathrm{DRBC}$ and the SRBC require metering, recording, and reporting with respect to withdrawal operations.

It should be noted that withdrawal operations might occur in a third state. Then all applicable requirements imposed by that state must be met. Similarly, trans-basin transportation might trigger the regulations of a river basin commission with jurisdiction at the point of withdrawal.

In the case of Exelon's Plant, the DRBC has approved the trial run as a stream flow augmentation demonstration project, which allows withdrawal even in low-flow conditions. The normal withdrawal fees apply. The withdrawal from the mine pool before discharge into the stream and the subsequent withdrawal from the stream trigger only one charge.

\subsubsection{Coordination of Approval to Withdraw Water Downstream with Discharge Upstream}

Basically two discharge scenarios are conceivable. One involves a constant discharge rate. The alternative is based on a variable discharge rate, depending on the stream flow. Regulators did not offer any specific guidance relative to requirements and policy surrounding the coordination between the approval to withdraw water downstream with the discharge operations upstream.

\footnotetext{
${ }^{44}$ Brannon, Bill, 2003, personal communication from B. Brannon (West Virginia Department of Environmental Protection, Division of Water and Waste Management, Executive Office) to M.G. Puder (Argonne National Laboratory).

${ }^{45}$ Brand, Thomas, 2003, personal communication from T. Brand (Delaware River Basin Commission) to M.G. Puder (Argonne National Laboratory).

${ }^{46}$ Hitz, Todd, 2003, personal communication from T. Hitz (Susquehanna River Basin Commission) to M.G. Puder (Argonne National Laboratory).
} 


\section{Chapter 7 - Costs}

The determination of costs associated with the use of mine pool water for power plant cooling depends on numerous factors, including water quality, location of the mine pool resource, and the water influent treatment requirements of the power plant's cooling or boiler system. Several small cogeneration plants in the anthracite coal fields of eastern Pennsylvania currently utilize mine pool water for their cooling systems (see Section 5-1). The cost information presented in this section was obtained from those facilities as well as from GenPower ${ }^{47}$, which has a proposed project to use mine pool water in the Pennsylvania/West Virginia border area (see Section 5.3).

\subsection{Withdrawal Costs}

Most of the plants that currently use or plan to use mine pool water for cooling, including GenPower's proposed Longview power plant, obtain mine pool water from existing mine shafts or outfalls. This eliminates the need for drilling costly large-diameter wells for water supply. Typically, vertical shaft pumps are used to remove the water from the mine pool. Depending on the distance to the power plant and the amount of hydraulic head that must be overcome, booster pumps may also be used. The cost of pumps depends on the horsepower and throughput capacity to meet the water requirements of the plant's cooling system. In the case of the Longview project, two vertical turbine pumps, each with a rated capacity of 3,500 gpm, would be used to supply water to the central treatment system. GenPower also plans to take advantage of existing pumps at some of the mines that are currently pumping water to smaller treatment systems. The total cost to install two 3,500-gpm rated pumps to supply water to the proposed Longview facility would be $\$ 600,000$.

For the Northeastern Power Company, pumping costs run at about $\$ 0.15 / 1,000$ gallons ( $\$ 7,500$ /year). It cost about $\$ 100,000$ in 1988 to build the pump house, install the pumps, and run the transport line.

In addition, certain River Basin Commissions (the DRBC and SRBC, but not ORSANCO and ORBC) charge surface water and groundwater withdrawal fees. Fees accrue for projects located in the Delaware and Susquehanna River basins. Thus, projects outside these basins (like the GenPower's Longview Power Plant) would not be subject to DRBC and SRBC withdrawal regulations. The charges for surface water withdrawal imposed by the DRBC amount to $\$ 60 /$ million gallons for consumptive use (loss of water through a man-made conveyance system) and \$0.60/million gallons for non-consumptive use. For example, Exelon's Limerick Plant, a large facility withdrawing on average 35 million gallons of mine pool water per day from the Wadesville Mine Pool, incurs \$2,100/day (\$764,000/year). In the case of the much smaller Northeastern Power Company the fee is $\$ 9 /$ day $(\$ 3,000 /$ year) for a withdrawal of 0.144 million gallons of mine pool water per day from the Silverbrook Mine Outfall. The charges levied by the SRBC are more than twice as high — \$140/million gallon — and apply to both groundwater and surface water withdrawals. For example, the Gilberton Power Company, which withdraws

\footnotetext{
${ }^{47}$ Colbert, Christopher, 2003, personal communication and email about the Longview Power Plant project from Colbert (GenPower, LLC) to J.M. Kupar (Argonne National Laboratory).
} 
about 1.2 million gallons of mine pool water per day from an unnamed mine pool, incurs \$170/day (\$62,000/year). The WPS Westwood Generation Plant, withdraws 1.152 million gallons of mine pool water per day from the Lyken Mine Pool and pays a little over \$161/day $(\$ 59,000 /$ year) to the SRBC. In general, the fees imposed by the River Basin Commissions are much lower than the costs of city water. The Gilberton Power Company, for example, has chosen the mine pool water over a new water main located just down the road.

\subsection{Transportation Cost}

Water is generally conveyed from the mine pool or outfall to the power plant using high-density polyethylene (HDPE) pipe. This further reduces the costs in comparison to using steel pipe. In an informal survey of the operators of the small cogeneration plants and the operator of the proposed larger Longview plant, the distance from the mine pool source to the power plant ranged from 0.5 to 6 miles. The cost for pipeline construction depends on the rating and diameter of the HDPE pipe as well as the terrain. For the Longview plant, GenPower estimated the cost of construction for the pipeline to be approximately $\$ 500,000$ per mile.

\subsection{Treatment Costs Before Water is Used for Cooling}

The water in most mine pools has characteristics that do not meet power plant process quality requirements. Typically, the $\mathrm{pH}$ of the water is too low and dissolved solids and metals need to be treated before use. Companies that want to use mine pool water for cooling must be prepared to treat the water before using it.

The most recent available cost estimate for the pretreatment of mine pool water for cooling systems comes from GenPower's proposed Longview facility. The treatment plant, which would have a rated design capacity of 7,000 gpm, was estimated to have a capital cost of $\$ 8.0$ million dollars $^{48}$. The major components of the plant would include:

- $\quad$ preaeration $\operatorname{tank}(\mathrm{s})$

- two parallel clarifiers

- chemical feed tanks

- metals precipitation /softener system

- thickener

- filter press

- process control systems

Costs will vary with the complexity of the mine pool water and the treatment requirements of the cooling water system. In the case of the Gilberton Power Company, treatment costs, estimated at $\$ 40,000$ are relatively minor, while the much smaller WPS Westwood Generation Plant incurs annual treatment costs at $\$ 75,000$ to $\$ 100,000$ for the chemicals alone. The annual treatment

\footnotetext{
${ }^{48}$ Colbert, Christopher, 2003, personal communication from C. Colbert (GenPower, LLC.) to J. Kupar (Argonne National Laboratory)
} 
costs relative to chemicals at the Northeastern Power Company come to $\$ 15,000(\$ 0.30 / 1,000$ gallons).

\subsection{Treatment Costs before Discharge or Injection}

The costs associated with this activity cannot be quantified at this time. The surveyed facilities that use mine pool water for cooling utilize their excess water for beneficial reuse options and have no need to discharge or inject that water. Several of the cogeneration plants that were surveyed in Pennsylvania use their discharge water for crop irrigation, aquaculture, or ash stabilization.

\subsection{Permitting Costs}

Most of the cogeneration plants that currently use mine pool water for cooling were constructed between the mid-1980s and mid-1990s. Much of the cost information related to permitting of their water treatment plants is not available. However, GenPower was able to provide current costs (2002) for permitting their 7,000-gpm water treatment system. GenPower estimates that the cost to permit the water treatment system at the Shannopin mine will be $\$ 70,000$.

\subsection{Summary Observations}

Despite costs associated with withdrawal, transportation, treatment and permitting, the use of mine pool water can lead to significant cost savings. In the case of Exelon's Limerick Plant cost savings accrue because pumping from Point Pleasant (on the Delaware River) is avoided. Costs of pumping water from Point Pleasant are very high due to a whole series of steps, streams, and reservoirs before the water arrives at the plant. The quality of the water from the Wadesville Mine Pool is high enough that no treatment is required. 


\section{Chapter 8 - Findings and Next Steps}

\subsection{Findings}

In many parts of the United States and the world, fresh water is in short supply. New demands for fresh water will not necessarily be met through traditional sources. In some parts of the country, vast quantities of water are collected in abandoned underground mines. The quality of this mine pool water varies from site to site, and often treatment is needed before it can be used. This report focuses on and evaluates only a subset of this potential water source: a) just coal mine pools; b) just those located in Pennsylvania and West Virginia; and c) just the use of mine pool water for power plant cooling and process purposes. Nevertheless, it points out the potential resource value of mine pools.

Although complete data on the volume of mine pool water in Pennsylvania and West Virginia are not available, the limited information compiled in this report suggests that there are at least hundreds of billions of gallons of water already in the mine pools. Details on the hydrology of those mine/groundwater systems are not well defined, and the sustainability of the resource (how fast will the mines refill as water is withdrawn) remains an important but unanswered question.

Mine pool water could potentially be used in at least four onsite cooling modes. The most likely use is as makeup water for a cooling system using a wet cooling tower (Mode 3 in this report). Six small power plants located in the anthracite region of Pennsylvania have been using mine pool water for cooling (Mode 3) for over a decade. This has proved very successful in those specific situations. From a cooling perspective, mine pool water is desirable because it has a relatively consistent and low temperature year round. In situations where mine pool water will be used as a seasonal water supply, the time of year when it is most likely to be used is during summer, low-flow periods. The cool mine pool water will be an effective cooling medium compared to the warmer surface waters that otherwise would be used.

An additional offsite mode relies upon using a stream or a river to transport treated mine pool water for some distance downstream before it is withdrawn for cooling use (Mode 5 in this report). Beginning in the summer of 2003, a large nuclear power plant owned and operated by Exelon in Limerick, Pennsylvania will conduct a trial to use mine pool water from a source located more than 70 miles upstream. The water will be discharged by the mine into a tributary to the Schuylkill River, and the river will transport the water to the power plant. If the trial is successful, Exelon may look for additional mine pool water sources to supplement its water supplies.

Although the six Pennsylvania plants mentioned above have been using mine pool water for many years, they have conducted relatively small-scale operations that use small volumes of water. Regulatory issues have been straightforward. If mine pools are to be used more widely in the future, particularly when more significant volumes of water are withdrawn for larger power plants, many regulatory and policy questions must be answered. It is well understood that water discharged from either mines or power plants to surface water bodies must be covered under NPDES permits. Heated water returned to a mine may be subject to requirements under the UIC 
program, but since mine pool water has never been used in that cooling mode before (Modes 2 or 4 in this report), the actual requirements are not known. Withdrawal of water from the mines in quantities sufficient for power plant purposes may trigger river basin regulations. Projects located in the Delaware and Susquehanna River basins are subject to all applicable withdrawal requirements imposed by the DRBC and the SRBC. Fees will be charged by the DRBC and the SRBC for the use of large volumes of water. Transport of water from one jurisdiction to another may require complex coordination.

The costs of pumping, piping, and treating mine pool water are highly site-specific and can be substantial. In some regions, no other sources of water are available in sufficient quantities; therefore, without using mine pool water, power plants could not operate economically in those locations.

Finally, environmental benefits can result in connection with the use of mine pool water at some locations. Throughout the coal regions of Pennsylvania and West Virginia, numerous mines are currently discharging to streams and rivers and others will soon overflow. Much of this water has undesirable qualities (low $\mathrm{pH}$; high iron, manganese, and TDS) and will cause degradation of the receiving water bodies. Any mine pool water that is removed from the pool by a power company represents water that will not contaminate the downstream portions of that stream or river. The authors are not aware of any circumstances yet under which government water resource or environmental agencies have offered financial incentives to potential users of the mine pool water, but as several large contaminated mine pools approach the overflow point, incentives may become part of a strategy to protect water quality. In any case, the concept of using an undesirable commodity (too much contaminated water) as a resource is quite attractive. This report offers background information that can be used to shape future policy and use of mine pool water.

\subsection{Next Steps}

This report presents evidence that the use of mine pool water is technically feasible, can be approved under existing regulatory authorities, and can be cost-effective. Nevertheless, mine pool water is not widely used today. Because other, more traditional fresh water sources have been available historically, there has been little incentive to explore new water supplies. Mine pool water is used already at some small facilities and is being investigated for use at several larger facilities. Before the resource can be more fully utilized, many questions will need to be answered, and industrial users, regulators, and the public must gain a better understanding of the value and potential impacts of using mine pool water.

Some of the areas that require further investigation include:

- better characterization of the locations and volumes of mine pools;

- better characterization of the variation in water quality parameters at various mine pools;

- hydrological information relating to recharge rates;

- $\quad$ the potential for ground surface subsidence as water is removed from mine pools; 
- the feasibility of using mine pools as heat sinks over several decades;

- costs associated with treatment, pumping, and piping mine pool water;

- development of clear policy on withdrawal of water;

- evaluation of mine pool resources in other states; and

- evaluation of mine pools from mines other than coal mines. 


\section{References}

Ash, S.H., W.L. Eaton, K. Hughes, W.M. Romischer, and J. Westfield, 1949, "Water Pools in Pennsylvania Anthracite Mines,” U.S. Bureau of Mines Technical Paper 727.

Ash, S.H., E.W. Felegy, D.O. Kennedy, and P.S. Miller, 1951, “Acid Mine Drainage Problems, Anthracite Region of Pennsylvania," U.S. Bureau of Mines Bulletin 508.

Cravotta, C.A., Brady, K.B.C., Rose, A.W., and Douds, J.B., 1999, "Frequency Distribution of the $\mathrm{pH}$ of Coal Mine Drainage in Pennsylvania," in Morganwalp, D.W., and Buxton., eds, U.S. Geological Survey Toxic Substances Hydrology Program - Proceedings of the Technical Meeting, Charleston, South Carolina, March 8-12, 1999: U.S. Geological Survey Water Resources Investigations Report 99-4018A.

Dodge, C.H. and Edmunds, W.F., 2003, “Coal Geology of Pennsylvania,” pp. 583-601, in 2003 Keystone Coal Industry Manual, Primedia Business Magazines and Media, Inc., Chicago, IL.

DOE, 2002, "Energy Penalty Analysis of Proposed Cooling Water Intake Structure Requirements on Existing Coal-Fired Power Plant," U.S. Department of Energy (Office of Fossil Energy, National Energy Technology Laboratory, and Argonne National Laboratory), October, $78 \mathrm{pp}$.

EEI, 1996, Environmental Directory of US Powerplants, Edison Electric Institute, Washington, D.C.

EIA, 2000, "Inventory of Electric Utility Power Plants in the United States 1999," DOE/EIA0095(99)/1, U.S. Department of Energy, Energy Information Administration, September.

EPA, 1996, "Draft Framework for Watershed-Based Trading,” EPA 800-R-96-001, U.S. Environmental Protection Agency.

EPRI, 1998, COOLADD: A Database of Power Plant Cooling Water Systems and Generic Chemical Additives Usage, developed by the Electric Power Research Institute, Palo Alto, CA, EPRI Report CM-109967-DK.

EPRI, 2003, Enhancement Strategies for Mitigating Potential Operational Impacts of Cooling Water Intake Structures, prepared by Argonne National Laboratory, for the Electric Power Research Institute, Palo Alto, CA, EPRI Report 1007454, 198 pp., May.

Feeley, T.J., III, and M. Ramezan, 2003, "Electric Utilities and Water: Emerging Issues and R\&D Needs," presented at the Water Environment Federation's $9^{\text {th }}$ Annual Industrial Wastes Technical and Regulatory Conference, San Antonio, TX, April 13-16. 
Feeley, T.J., III, undated, “Innovations for Existing Plants Program - DOE/NETL's Power PlantWater R\&D Activities," PowerPoint presentation provided by Feeley, DOE National Energy Technology Laboratory, to J.A. Veil, Argonne National Laboratory, September 2003.

Growitz, D.J., Reed, L.A., and Beard, M.M., 1985, "Reconnaissance of Mine Drainage in the Coal Fields of Eastern Pennsylvania," Water Resources Investigations Report 83-4274, U.S. Geological Survey, Harrisburg, PA.

Jehl, 2003, “A New Frontier in Water Wars Emerges in East," Douglas Jehl, The New York Times, March 3, 2003.

Micheletti, W.C., 2003, electronic mail and Microsoft Excel spreadsheet file containing flow versus capacity data, sent by Micheletti, Wayne C. Micheletti, Inc., Charlottesville, VA, to J. Veil, Argonne National Laboratory, July 30.

Micheletti, W.C., and J. M. Burns, 2002, "Emerging Issues and Needs in Power Plant Cooling Systems," presented at the Water Issues in Fossil Energy Workshop, National Energy Technology Laboratory, Pittsburgh, PA, June 27.

Office of Surface Mining, 2002, "Permitting Hydrology, A Technical Reference Document for Determination of Probable Hydrogeologic Consequences (PHC) and Cumulative Hydrogeologic Assessments (CHIA)," Office of Surface Mining, U.S Department of the Interior, Washington, D.C.

PADEP Fact Sheet, 2000, "Environmental Good Samaritan Act," Commonwealth of Pennsylvania, Department of Environmental Protection, May 2000.

Peng, S.S., 1978, Coal Mine Ground Control, John Wiley \& Sons, New York, NY.

Penn State, 1997, “A Primer on Access and Allocation of Water in Pennsylvania," Pennsylvania State University, College of Agricultural Sciences, 1997.

PPRP, 2002, "PPRP Power Plant Update," prepared by the Maryland Department of Natural Resources, Power Plant Research Program, Annapolis, MD, volume 6, number 2, winter.

Reed, R.A., Beard, M.M., and Growitz, D.J., 1985, "Quality of Water in Mines in the Middle Coal Field, Anthracite Region, East Central Pennsylvania," Water Resources Investigations Report 85-4038, U.S. Geological Survey, Harrisburg, PA.

Repine Jr., T.E., B.M. Blake, K.C. Ashton, N. Fedorko III, A.F. Keiser, E.I. Loud, C.J. Smith, S.W. McClelland, and G.H. McColloch, 1992, "Regional and Economic Geology of Pennsylvania Age Coal Beds of West Virginia," International Journal of Coal Geology, 23 (1993) 75-101, Elsevier Science Publishers B.V., Amsterdam, The Netherlands.

USGS, 1998, "Estimated Use of Water in the United States in 1995," U.S. Geological Survey. 
Veil, J.A., 1997, “The Feasibility of Effluent Trading in the Energy Industries," prepared by Argonne National Laboratory for the U.S. Department of Energy, Washington, D.C., May.

Veil, J., 1998, “The Potential for Effluent Trading in the Energy Industries," Environmental Science and Policy 1:39-49.

West Virginia Coal Association, 2001, “Coal Facts 2001," West Virginia Coal Association, Charlestown, WV.

Wood, C.R., 1995, "Water Quality of Large Discharges from Mines in the Anthracite Region of Eastern Pennsylvania," Water Resources Investigations Report 95-4243, U.S. Geological Survey, Lemoyne, PA. 


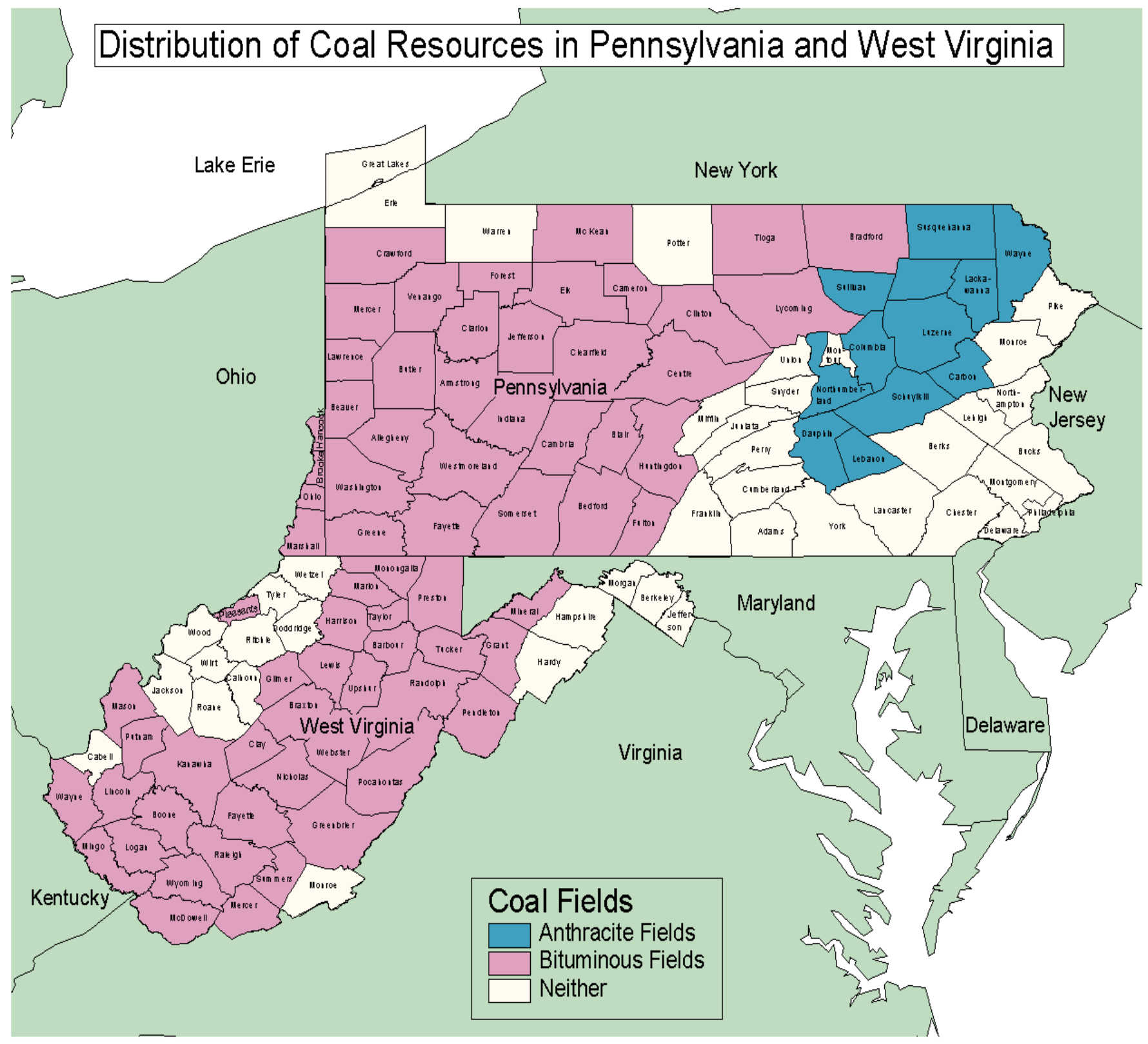

Figure 2-1 Distribution of Coal Resources in Pennsylvania and West Virginia (Information used to develop this map was obtained from the USGS and PADEP) 


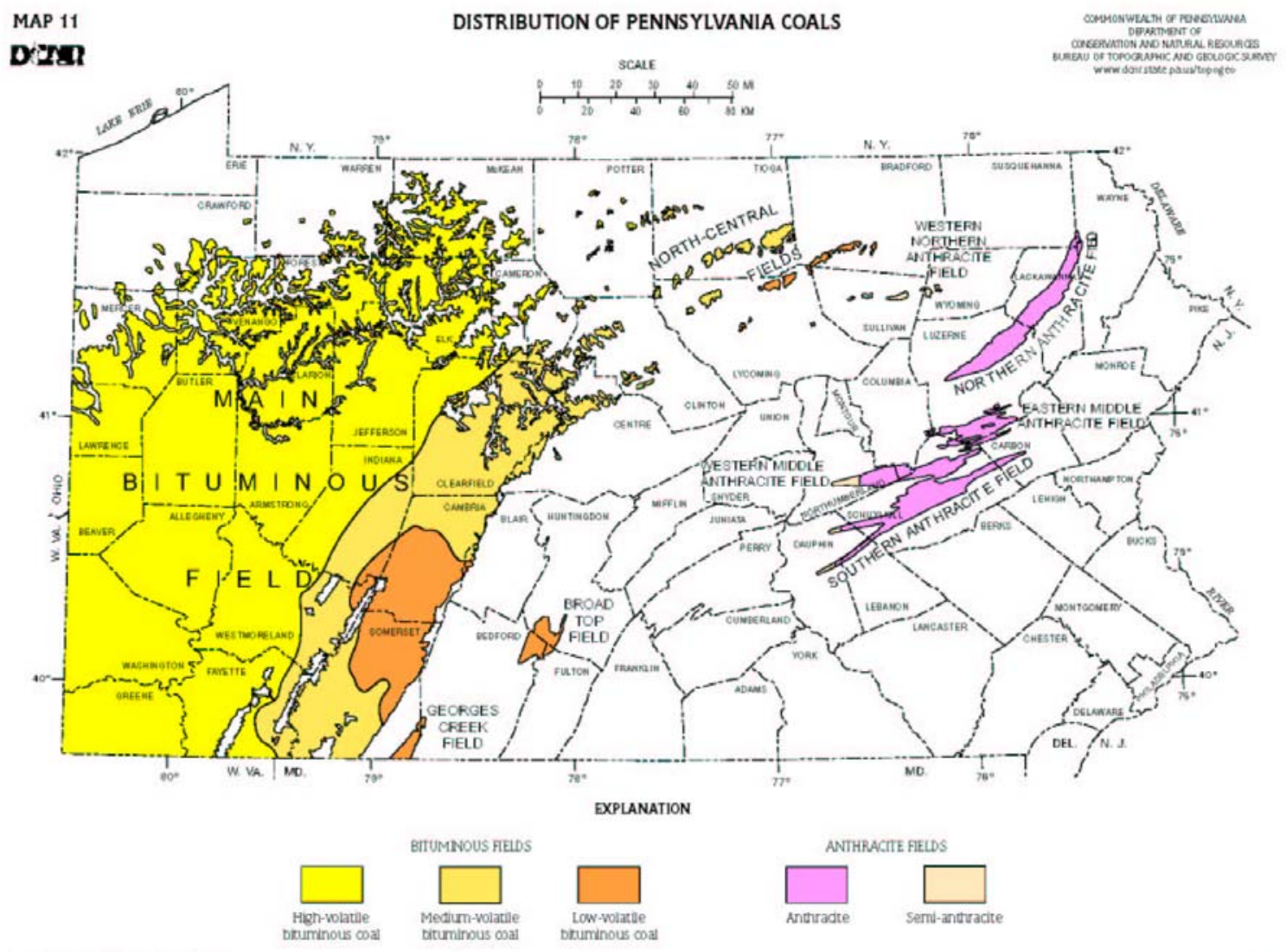

Figure 2-2 Distribution of Coal Fields in Pennsylvania Source: Pennsylvania Geological Survey, Map 11 (http://www.dcnr.state.pa.us/topogeo/maps/map11.pdf) 


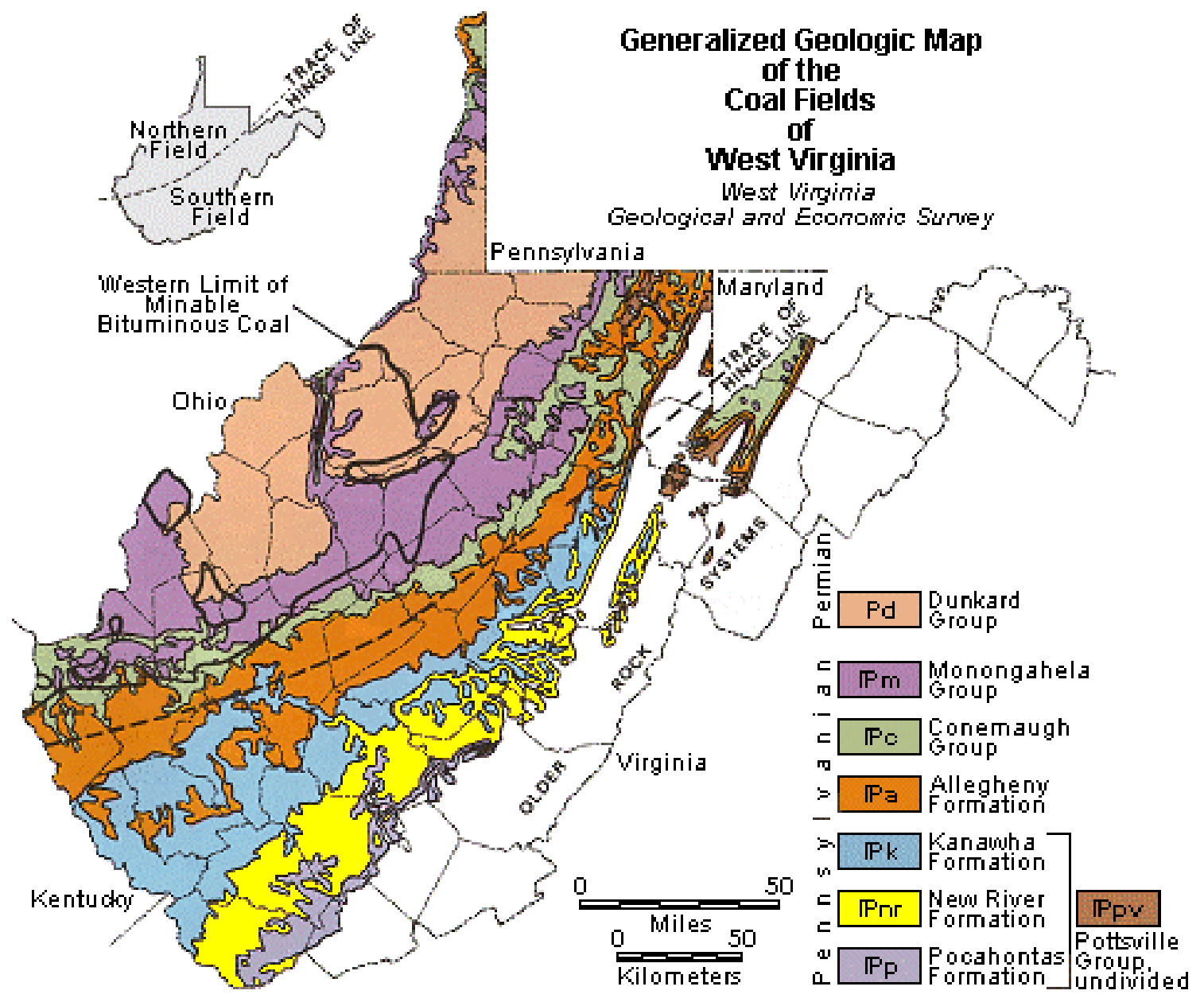

Figure 2-3 Distribution of Coal Fields in West Virginia Source: West Virginia Geological and Economic Survey

(http://ims.wvgs.wvnet.edu/geology.htm) 
Mine Discharges In Pennsylvania

Discharges Greater Than or Equal to 250 GPM Average

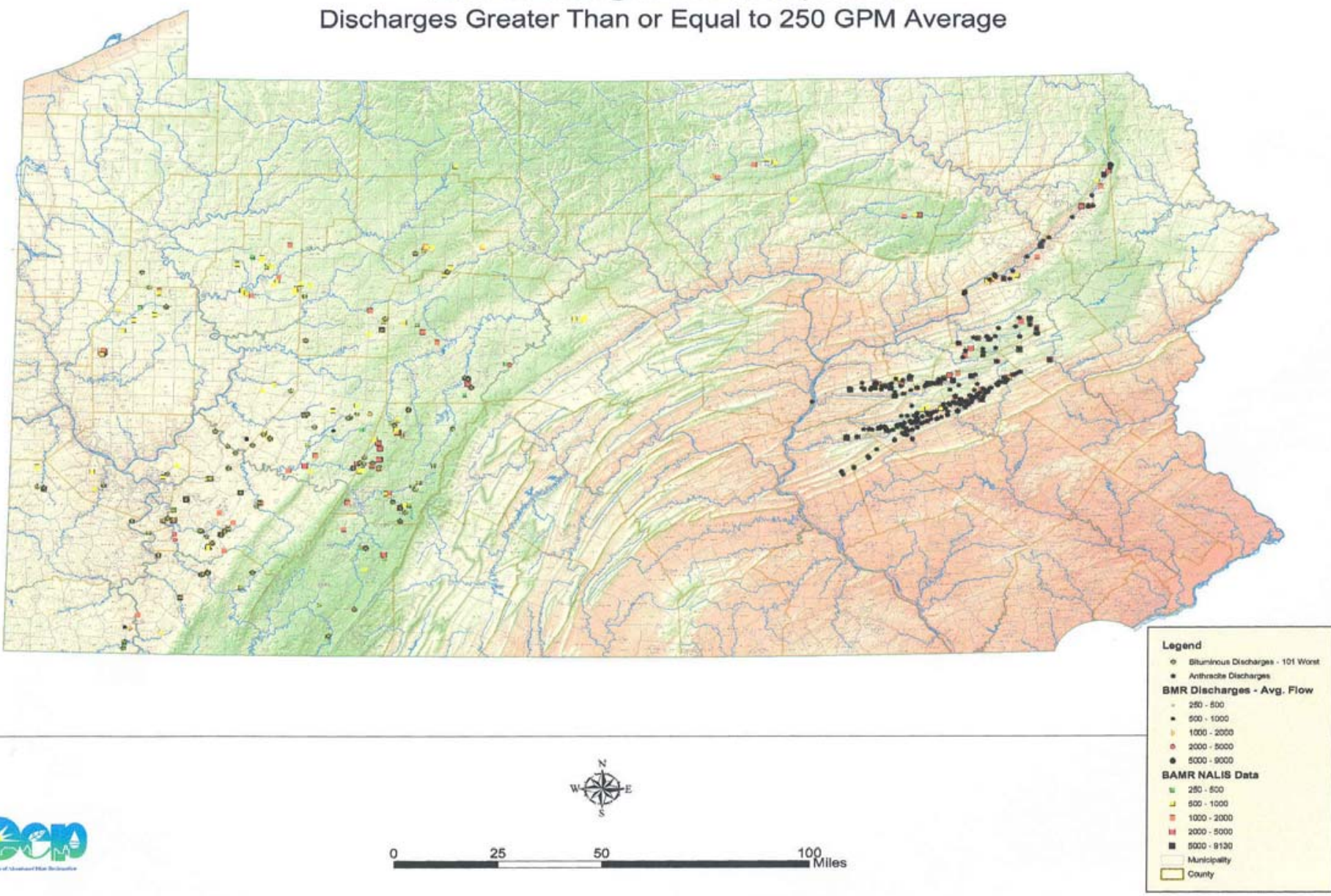

Figure 2-4 Mine Discharges in Pennsylvania - Discharges Greater Than or Equal to $250 \mathrm{gpm}$

Source: Pennsylvania Department of Environmental Protection 

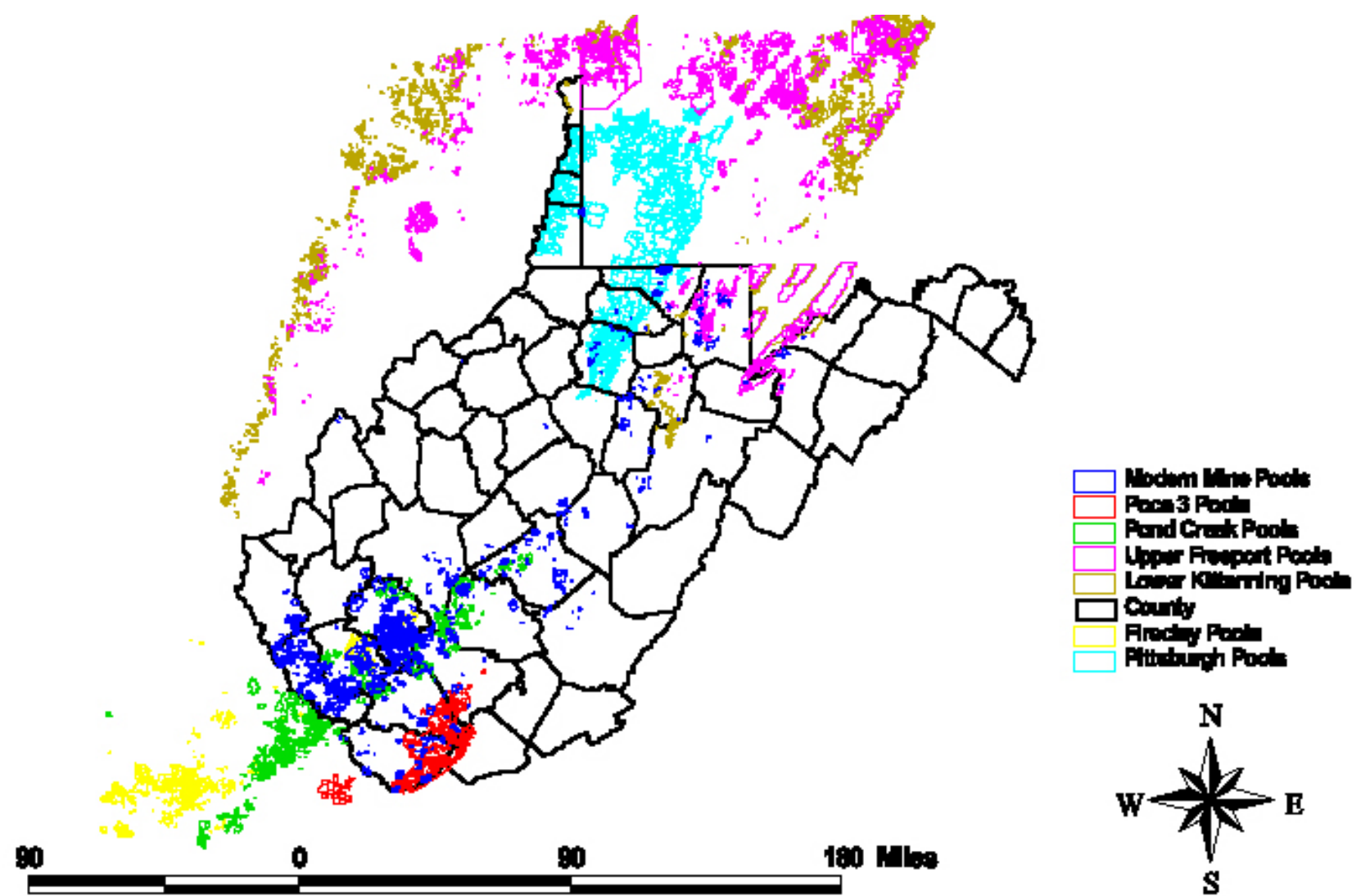

Figure 2-5 Known Underground Mine Water Discharge Locations

Source: West Virginia Geological and Economic Survey 


\section{Once-Through Cooling Modes}

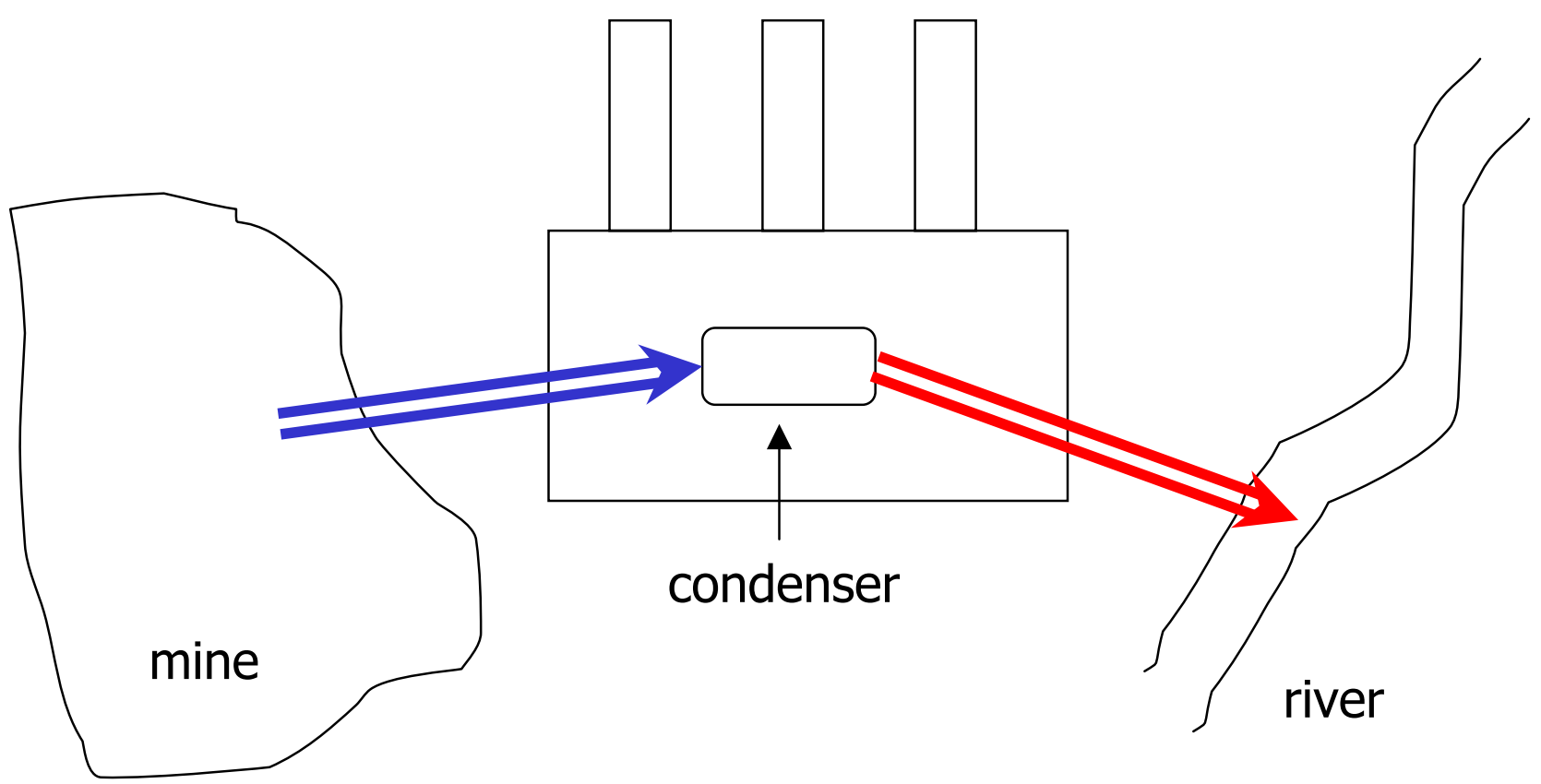

Figure 3-1 Mode 1 - Once-Through with Discharge
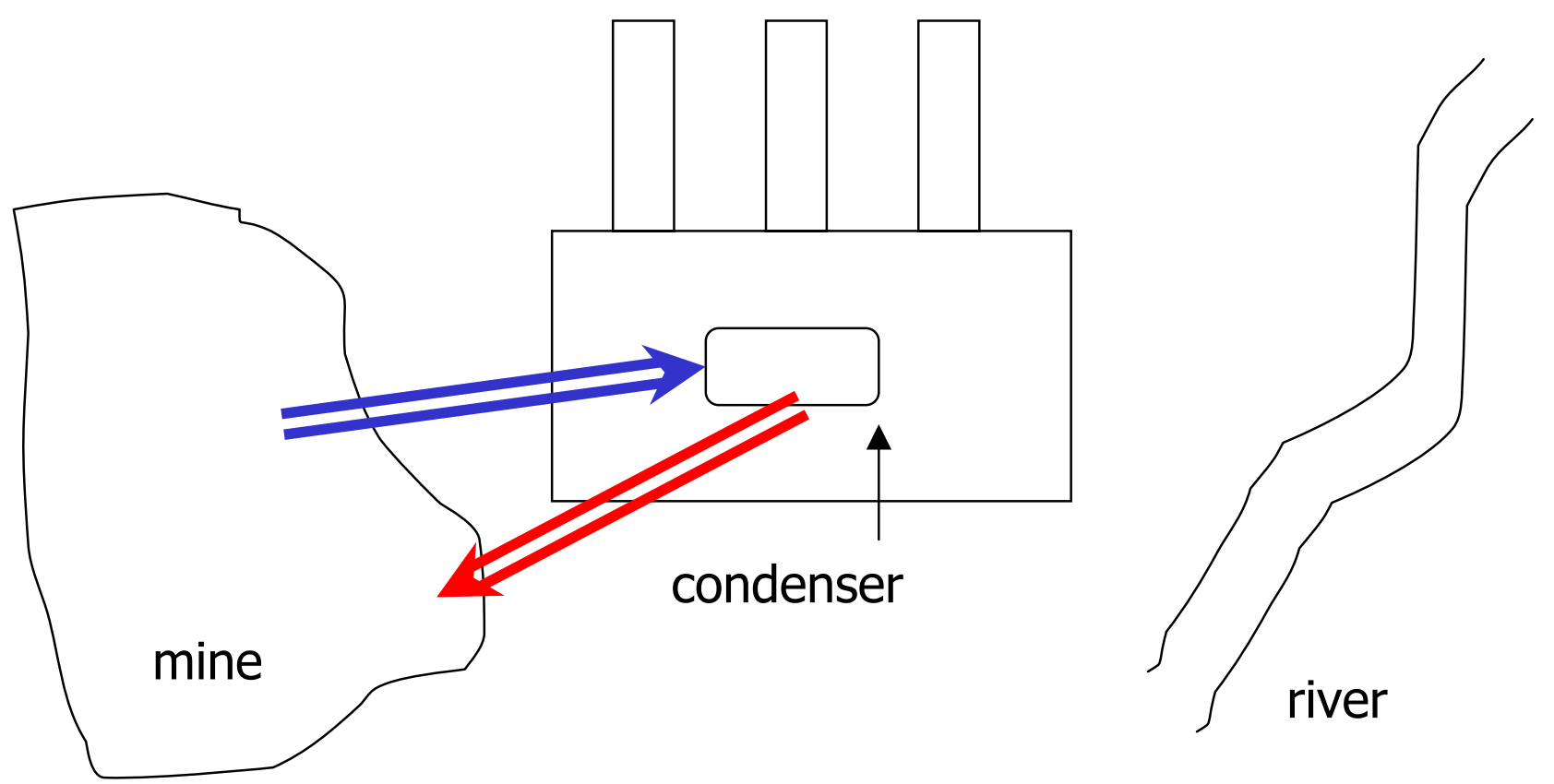

Figure 3-2 Mode 2 - Once-Through, Return to Pool 


\section{Closed-Cycle Cooling Modes}

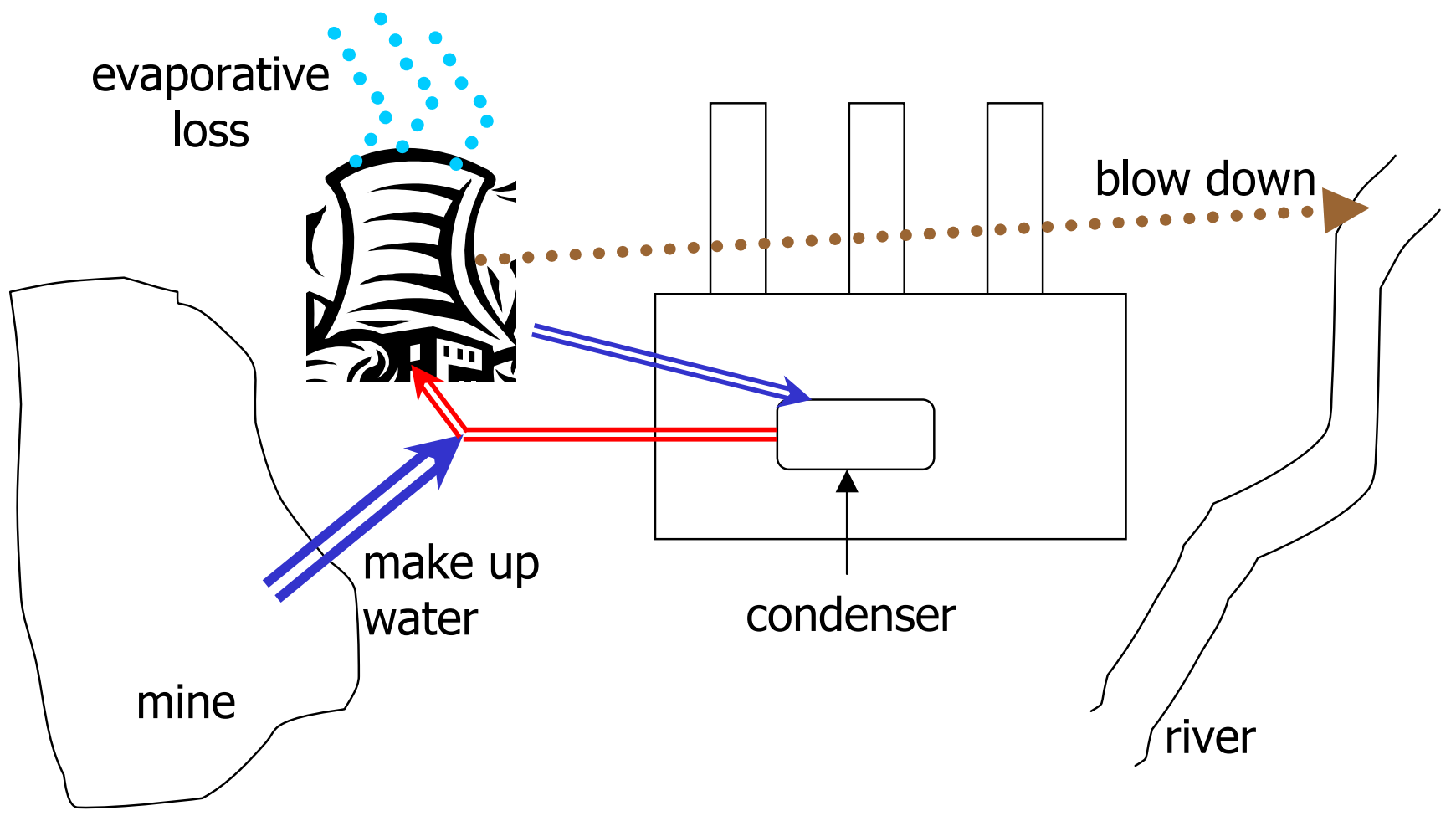

Figure 3-3 Mode 3-Closed-Cycle, Wet Tower

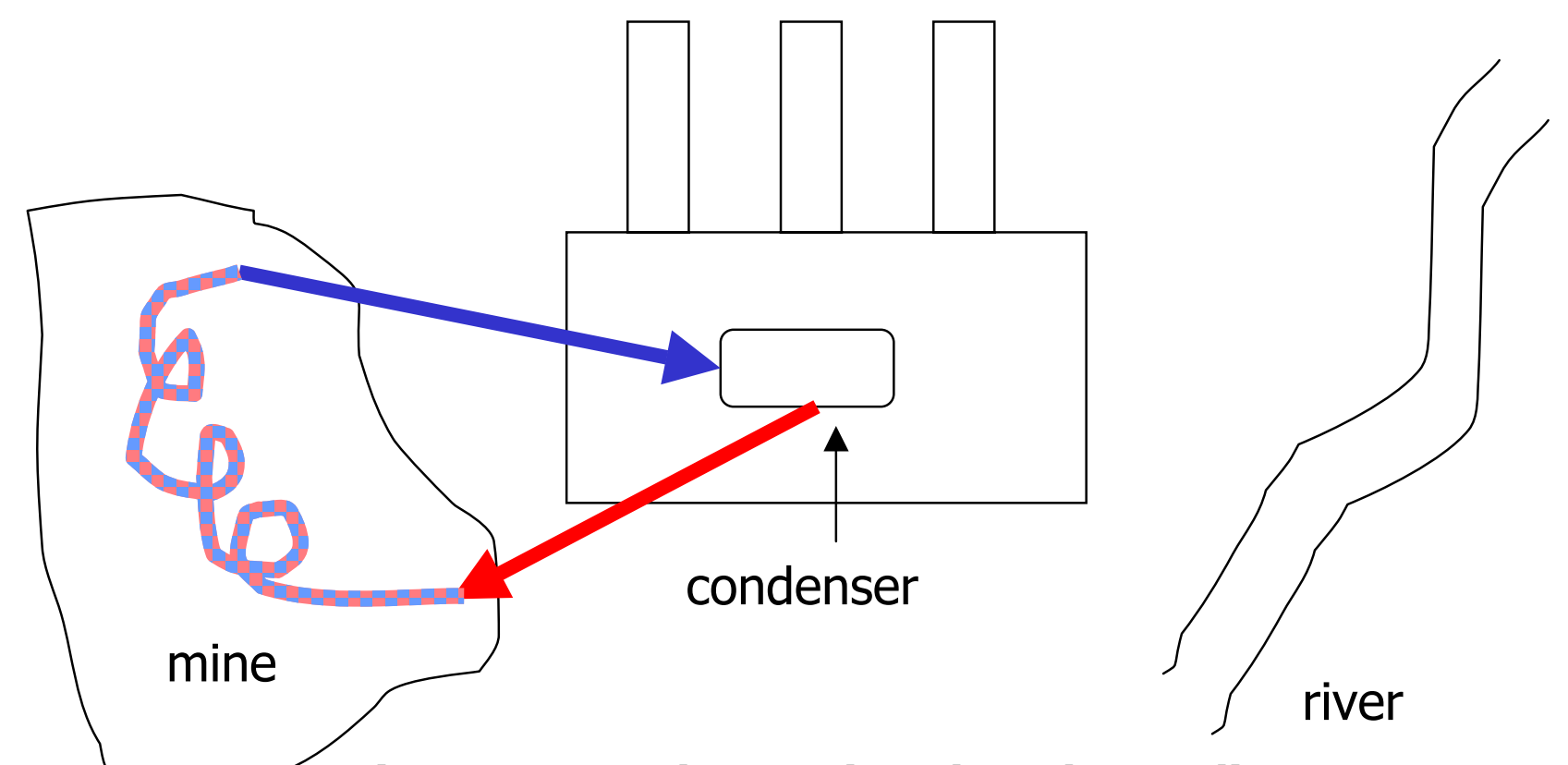

Figure 3-4 Mode 4-Closed-Cycle, Cooling Loop 


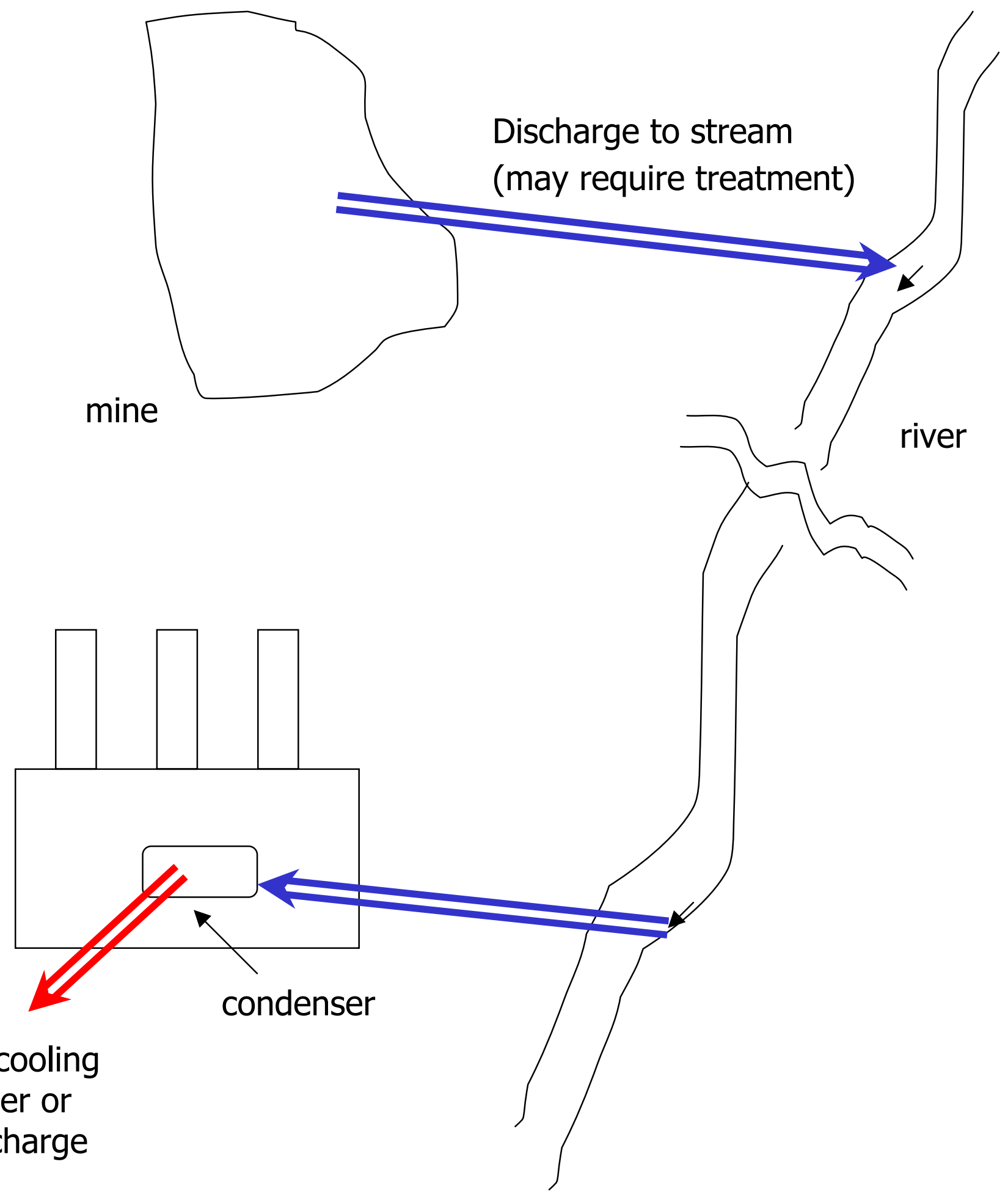

Figure 3-5 Mode 5 - Downstream Use after Instream Transport 


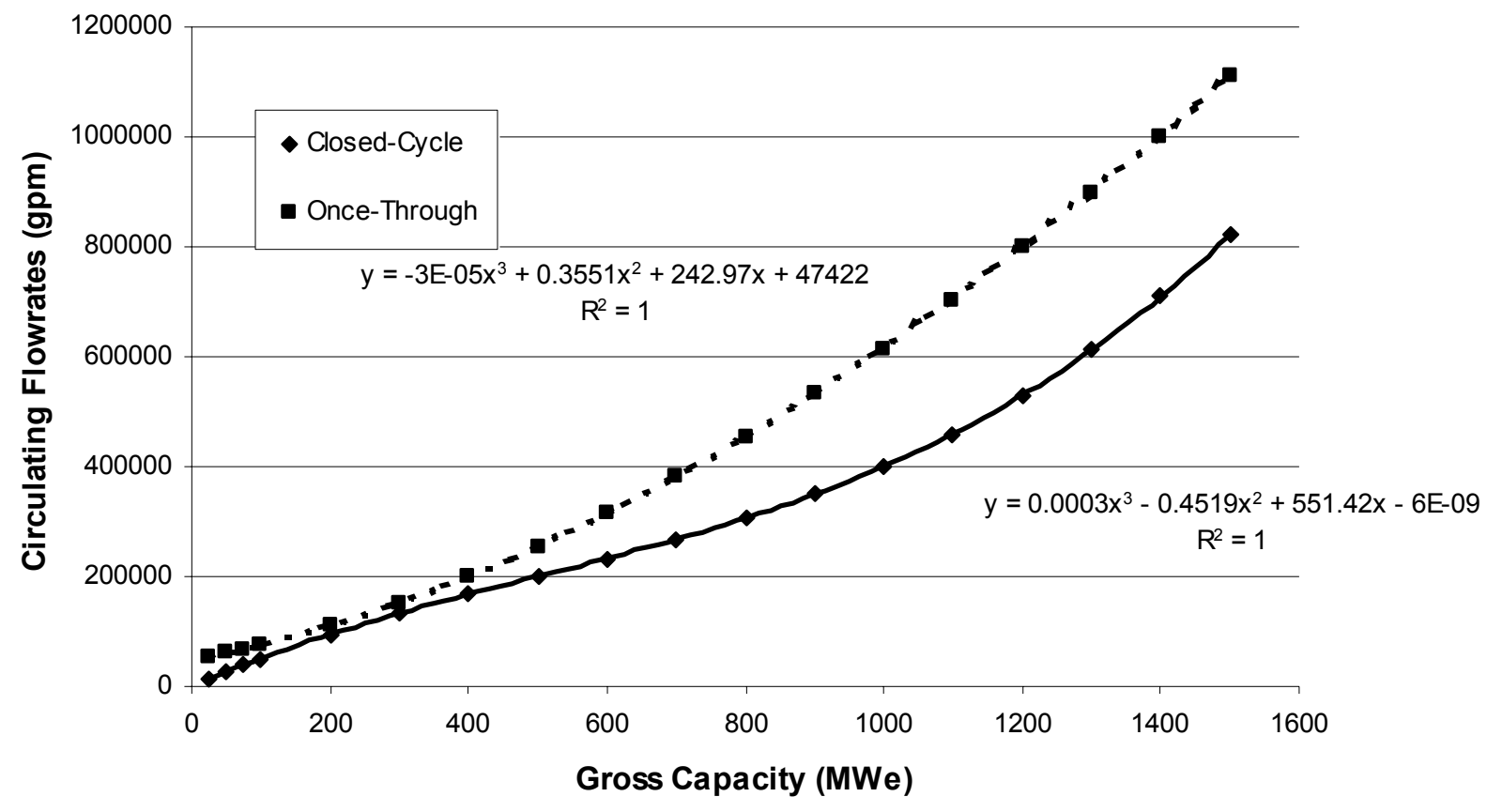

Figure 3-6: Cooling System Circulating Flowrates; Source: Micheletti (2003a)

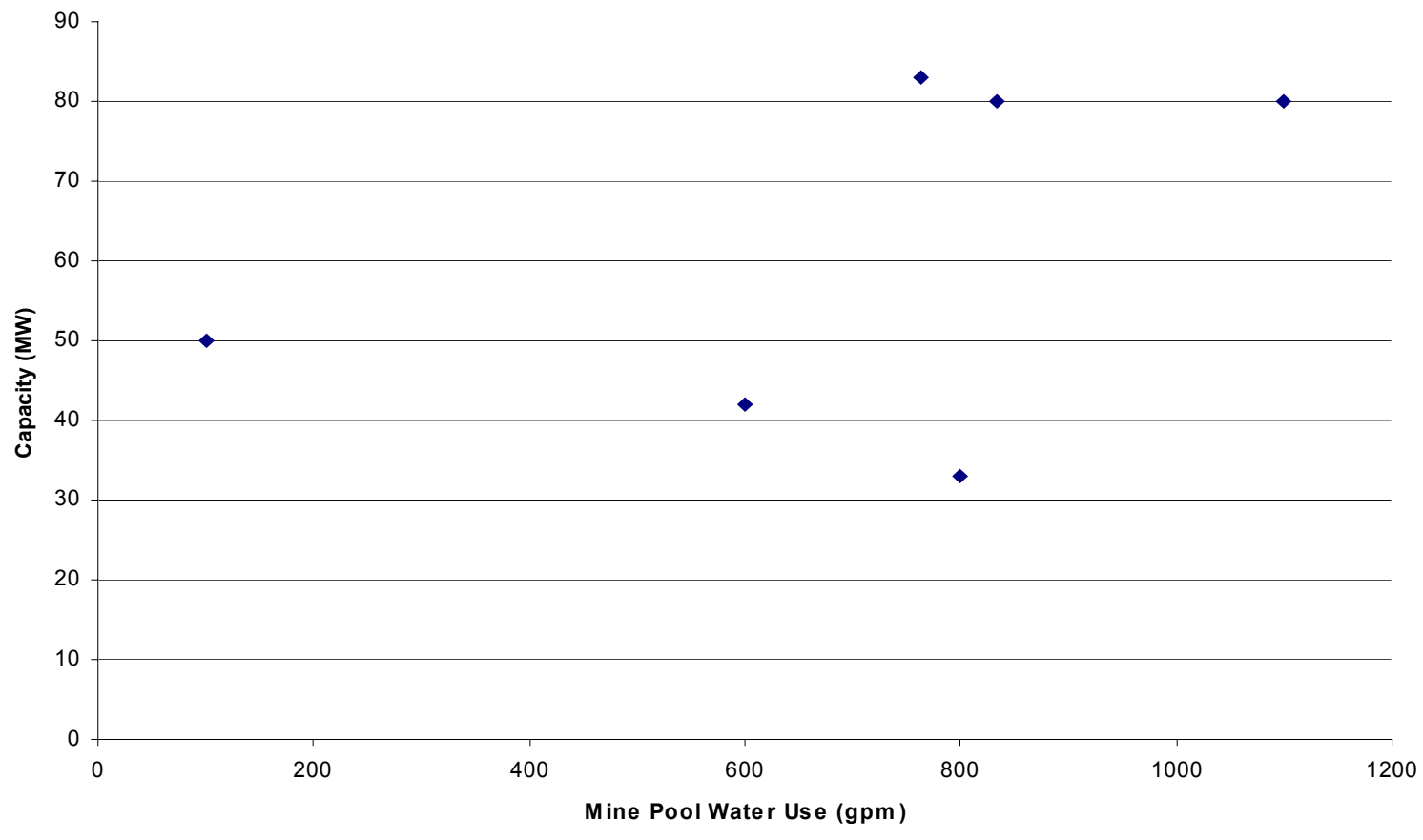

Figure 3-7: Mine Pool Water Use vs. Capacity at Six Small Cogeneration Facilities 